WSRC-STI-2006-00033

Revision 1

\title{
FLUIDIZED BED STEAM REFORMER (FBSR) PRODUCT: MONOLITH FORMATION AND CHARACTERIZATION
}

C.M. Jantzen

June 2006

Process Science \& Engineering Section Savannah River National Laboratory Aiken, SC 29808

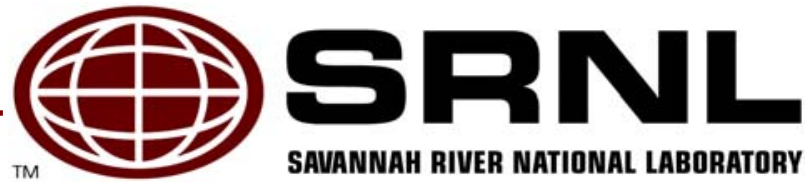

Prepared for the U.S. Department of Energy Under Contract Number DEAC09 96SR18500 


\section{DISCLAIMER}

This report was prepared by Washington Savannah River Company (WSRC) for the United States Department of Energy under Contract No. DE-AC09-96SR18500 and is an account of work performed under that contract. Neither the United States Department of Energy, nor WSRC, nor any of their employees makes any warranty, expressed or implied, or assumes any legal liability or responsibility for the accuracy, completeness, or usefulness, of any information, apparatus, or product or process disclosed herein or represents that its use will not infringe privately owned rights. Reference herein to any specific commercial product, process, or service by trademark, name, manufacturer or otherwise does not necessarily constitute or imply endorsement, recommendation, or favoring of same by WSRC or by the United States Government or any agency thereof. The views and opinions of the authors expressed herein do not necessarily state or reflect those of the United States Government or any agency thereof.

\section{Printed in the United States of America}

Prepared For U.S. Department of Energy 
Key Words: low activity waste, Hanford, ceramic waste form, mineral waste form

Retention: Permanent

\section{FLUIDIZED BED STEAM REFORMER (FBSR) PRODUCT: MONOLITH FORMATION AND CHARACTERIZATION}

C.M. Jantzen

June 2006

Process Science \& Engineering Section Aqkann, se 29808 National Laboratory

Prepared for the U.S. Department of Energy Under Contract Numb DEAC09-96SR18500

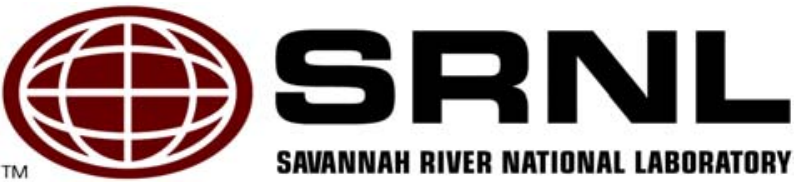




\section{REVIEWS AND APPROVALS}

\section{AUTHOR:}

Carol M. Jantzen, Pfocess Sfience \& Engineering

$6-14-06$

Date

TECHNICAL REVIEWERS:

Peter W. Gibbons, Engineer, Columbia Basin Consulting Group $\frac{6-14-2006}{\text { Date }}$

$6-14-06$

Bradley Mason, Chief Engineer, Thor® Treatment Technologies

Date

$6 / 29 / 06$

Jamhes C. Marra, Materials Science \& Technology

Date

\section{APPROVERS}

\begin{tabular}{lc} 
& $7 / 3 / 06$ \\
\hline Richard E. Edwards, Manager, Process Science \& Engineering & Date
\end{tabular}

David A. Crowley, Manager, Stabilization Science Research $6\left(\frac{21 / 06}{\text { Date }}\right.$ 


\section{EXECUTIVE SUMMARY}

The most important requirement for low activity waste (LAW) form acceptance for shallow land burial is the chemical durability of the product. Of secondary, but important concern, is the compressive strength of the material. The THOR ${ }^{\circledR}$ Treatment Technologies (TTT) mineral waste form for low activity waste is granular in nature. As a granular product it has been shown to be as durable as low activity waste (LAW) glass. This is partially due to the high aluminosilicate content of the mineral product which provides an aluminosilicate buffering mechanism that inhibits leaching and that is known to occur in aluminosilicate minerals in nature.

An additional requirement is the strength of the material under shallow land disposal conditions, e.g. the weight of soil overburden and potential intrusion by future generations, since the term "near-surface disposal" indicates disposal in the uppermost portion, or approximately the top 30 meters, of the earth's surface. The strength requirement requires that a waste form be a monolith and have a minimum compressive strength of 500 psi after 28 days curing.

The Fluidized Bed Steam Reformer (FBSR) mineral product formulated into monoliths and tested was a mixture of FBSR bed material produced at the Science Applications International Corporation (SAIC) Science and Technology Applications Research (STAR) facility in Idaho Falls, ID with Idaho National Laboratory Sodium Bearing Waste (SBW) and Hanford Low Activity Waste (LAW). Bed products and fines from these 2003-2004 pilot scale tests were mixed. The coal was roasted out at a low temperature so as to be more representative of the THOR ${ }^{\circledR}$ Treatment Technologies (TTT) most recent flowsheet which includes a Carbon Reduction Reactor (CRR). The mixed bed and fines FBSR products were chemically analyzed and determined to be $\sim 45$ $\mathrm{wt} \% \mathrm{Al}_{2} \mathrm{O}_{3}$ startup bed, $\sim 17 \mathrm{wt} \% \mathrm{SBW}$ mineral waste form from 2003-2004 testing and $\sim 20 \mathrm{wt} \%$ LAW waste form from 2004 testing. The contribution of the LAW04 material to the composite may be underestimated since $\mathrm{SO}_{3}$ is very high in the as measured composite and the LAW mineral products (bed and fines) are the largest contributors to the $\mathrm{SO}_{3}$ content. This may be due to the fact that the $\mathrm{SO}_{3}$ in the nosean phase was not evenly distributed in the 2004 sample products either before or after the composite was mixed.

Five concrete monoliths with FBSR waste loadings between $80-87 \mathrm{wt} \%$ were fabricated. One Ceramicrete monolith at a waste loading of $35.7 \mathrm{wt} \%$ FBSR and three hydroceramic monoliths with waste loadings between 50-80 wt \% FBSR were fabricated. The Hanford contract specification (Section 2.2.2.2) requires that the $\mathrm{Na}_{2} \mathrm{O}$ loading in $\mathrm{wt} \%$ of the waste form for Envelope A wastes, wastes that are high sodium characteristic wastes, be $14 \mathrm{wt} \%$. The starting FBSR product used in this study contained $20.87 \mathrm{wt} \% \mathrm{Na}_{2} \mathrm{O}$ from Envelope A waste. Therefore, one can calculate that an Envelope A FBSR product would have to have $\geq 67 \mathrm{wt} \%$ FBSR loading in order to meet the Envelope A waste loading specification. It should be noted that the Hanford Envelope A waste loading specification is more stringent than the remaining $\mathrm{Na}_{2} \mathrm{O}$ waste loadings which are $3 \mathrm{wt} \%$ 
for Envelope B wastes, which are high sulfate characteristic wastes, and $10 \mathrm{wt} \%$ for Envelope $\mathrm{C}$ wastes, which are high organic characteristic wastes. It should also be noted that the waste loadings tested do not necessarily represent the maximum practical waste loading for each binder, as that was not a primary objective of this study. The primary objective of this study was to determine if a binder had an adverse reaction on or with the FBSR product's ability to retain waste components while achieving a minimum of 500 psi compressive strength.

All but one of the cement monolith formulations had $>500$ psi compressive strength after 7 days. The Ceramicrete monolith had the highest density and compressive strength of all the monoliths tested but the lowest waste loading tested. The $80 \%$ waste loaded hydroceramics had the highest compressive strength of all the hydroceramics tested indicating that the FBSR mineral products were participating in the monolithing reactions giving additional strength and density.

All of the monoliths met the $<2 \mathrm{~g} / \mathrm{m}^{2}$ durability specification for $\mathrm{Na}$ and $\mathrm{Re}$ (simulant for $\mathrm{Tc}^{99}$ ) when tested using the Product Consistency Test (PCT; ASTM C1285) except for cement formulation D. Of the nine monoliths tested the three highest loaded $(80-87 \mathrm{wt} \%$ FBSR product) cements, the Ceramicrete, and the highest waste loaded hydroceramic (83.3 wt\% FBSR product) met the compressive strength and durability requirements for an LAW waste form. While the waste loading criteria was not optimized for the Ceramicrete, the cementitious and hydroceramic waste forms exceeded the waste loading criteria for Hanford Envelope A wastes, e.g. $67 \mathrm{wt} \%$ FBSR product. The waste loading criteria is lower for Envelope $\mathrm{B}$ and $\mathrm{C}$ wastes. The five monoliths that met the Envelope A waste loading criteria also met the Envelope $\mathrm{C}$ waste loading criteria of $47 \mathrm{wt} \% \mathrm{FBSR}$ product. All five monoliths that passed the PCT and compressive strength exceeded the $14 \mathrm{wt} \%$ FBSR waste loading for Envelope B wastes. 


\section{TABLE OF CONTENTS}

EXECUTIVE SUMMARY Ii

LIST OF FIGURES $\quad$ v

LIST OF TABLES Ni vi

LIST OF ACRONYMS vii

$\begin{array}{ll}1.0 \text { INTRODUCTION } & 1\end{array}$

2.0 Background 2

2.1 Required Low Activity Waste (LAW) Form Durability Testing 2

2.2 Compressive Strength

2.3 Waste Loading $\quad 6$

3.0 QUALITY ASSURANCE $\quad 6$

.0 EXPERIMENAL $\quad 6$

4.1 Initial Waste Characterization $\quad 6$

4.2 Cement Monoliths $\quad 8$

$\begin{array}{lr}4.3 \text { Ceramicrete Monoliths } & 10\end{array}$

4.4 Hydroceramic Monoliths 11

4.5 Monolith Characterization $\quad 12$

4.6 Density and Compression Testing 14

4.7 Durability Testing 15

$\begin{array}{ll}\text { 5.0 RESULTS } & 17\end{array}$

5.1 Initial Waste Characterization 17

5.2 Monolith Density and Compressive Strength 20

5.3 Monolith Characterization and Waste Loading $\quad 22$

5.4 Monolith Durability Testing 24

$\begin{array}{ll}\text { 6.0 CONCLUSIONS } & 35\end{array}$

7.0 RECOMMENDATIONS/PATH FORWARD 35

8.0 ACKNOWLEDGEMENTS 36

$\begin{array}{ll}9.0 \text { REFERENCES } & 37\end{array}$ 


\section{LIST OF FIGURES}

Figure 1. Teflon ${ }^{\circledR}$ molds used in cement and hydroceramic monolith formation.

Figure 2. Cement monoliths after setting for 7 days and before compression and durability testing. .10

Figure 3. Ceramicrete monoliths before Compression and durability testing. .11

Figure 4 . Stainless steel molds used in cement and hydroceramic monolith formation. .12

Figure 5. Hydroceramic blocks Set 1 (left) and Set 2 (right)....... .13

Figure 6. Hydroceramic blocks Set 3 .

Figure 7. Compression testing by ASTM C109-02 (left upper and lower) and ASTM C39-04A (right).

Figure 8. Comparative FBSR loadings (dry wt $\%$ basis) in monolith and compressive strengths.

Figure 9. Comparative BET surface area $\left(\mathrm{m}^{2} / \mathrm{g}\right)$ of STAR and Hazen FBSR bed and fines products to the surface area of the STAR products embedded in concrete, Ceramicrete, and hydroceramics.

Figure 10. Monolith $\mathrm{pH}$ values from PCT testing compared to $\mathrm{pH}$ values of initial FBSR bed products.

Figure 11. PCT triplicate leachate analyses for Al, Si, S, and Cs in $\mathrm{g} / \mathrm{m}^{2}$. 33

Figure 12. PCT triplicate leachate analyses for $\mathrm{Na}$ and $\mathrm{Re}$ in $\mathrm{g} / \mathrm{m}^{2}$. .34 


\section{LIST OF TABLES}

Table 1 Pilot Scale FBSR Samples Tested in 2003-2004 at the SAIC STAR Facility 7

Table 2. SRNL Cement Monolith Formulations $\quad 8$

Table 3. SRNL Hydroceramic Monolith Formulations and Curing Conditions 13

Table 4. Oxide and Anion (Sodium Salt) Analyses of Steam Reformer Composite (Bed $\begin{array}{ll}\text { Products and Fines) Monolithed } & 19\end{array}$

Table 5. SRNL Monolith Density (g/cc) and Compressive Strength (psi) 21

Table 6. Theoretically Calculated LAW Envelope A Waste Loadings Based on $\mathrm{Na}_{2} \mathrm{O}$ $(\mathrm{wt} \%)$

Table 7. X-ray Diffraction Analysis of Phases in the FBSR Composite Before and After Monolithing

Table 8. Chemically Analyzed Composition (wt $\%$ ) of Monoliths on Hydrous Basis 25

Table 9. Chemically Analyzed Composition (wt\%) of Monoliths on Anhydrous Basis 26

Table 10. Measured BET Surface Area and Geometric Surface Area in $\mathrm{m}^{2} / \mathrm{g} \quad 27$

Table 11. PCT Leachate standards and blanks (ppm) 28

Table 12. PCT Leachate Standards (g/L) 28

Table 13. PCT Leachate Concentrations (ppm) 29

Table 14. PCT Leachate Concentrations $\left(\mathrm{g} / \mathrm{m}^{2}\right) \quad 30$

Table 15. Average of Triplicate PCT Results Expressed $10^{-3} \mathrm{~g} / \mathrm{m}^{2}$

Table 16. Summary of Monolith Performance Vs. Development Criteria 35 


\section{LIST OF ACRONYMS}

\begin{tabular}{|l|l|}
\hline ANL & Argonne National Laboratory \\
\hline ANS & American Nuclear Society \\
\hline ANSI & American National Standards Institute \\
\hline ASTM & American Society for Testing Materials \\
\hline CRR & Carbon Reduction Reactor \\
\hline CGW & Corning Glass Works \\
\hline DMR & Denitration Mineralizing Reactor \\
\hline DOE & Department of Energy \\
\hline DWPF & Defense Waste Processing Facility \\
\hline EA & Environmental Assessment \\
\hline FBSR & Fluidized Bed Steam Reformer \\
\hline HIC & High Integrity Container \\
\hline HLW & High Level Waste \\
\hline IC & Ion Chromatography \\
\hline ICP-ES & Inductively Coupled Plasma - Emission Spectroscopy \\
\hline ICP-MS & Inductively Coupled Plasma - Mass Spectroscopy \\
\hline ILAW & Immobilized Low Activity Waste \\
\hline INL & Idaho National Laboratory \\
\hline LAW & Low Activity Waste \\
\hline MCC & Materials Characterization Center \\
\hline NAS & Na-Al-Si \\
\hline OPC & Ordinary Portland Cement \\
\hline PCT & Product Consistency Test \\
\hline PSU & Pennsylvania State University \\
\hline RMSE & Root Mean Square Error \\
\hline SA & Surface Area \\
\hline SAIC & Science Applications International Corporation \\
\hline SBW & Sodium Bearing Waste \\
\hline SEM & Scanning Electron Microscopy \\
\hline SPFT & Single Pass Flow Through \\
\hline SRS & Savannah River Site \\
\hline SRNL & Savannah River National Laboratory \\
\hline STAR & Science and Technology Applications Research \\
\hline TTT & THOR ${ }^{\circledR}$ Treatment Technologies \\
\hline THOR & THermal Organic Reduction \\
\hline VHT & Vapor Hydration Test \\
\hline WAPS & Waste Acceptance Product Specifications \\
\hline WCP & Westinghouse Savannah River Company \\
\hline WSRC & \\
\hline WFO & Work For Others \\
\hline WL & XRD \\
\hline
\end{tabular}




\title{
FLUIDIZED BED STEAM REFORMER (FBSR) PRODUCT: MONOLITH FORMATION AND CHARACTERIZATION
}

\author{
C.M. Jantzen \\ Savannah River National Laboratory \\ Aiken, SC 29808
}

\subsection{INTRODUCTION}

The most important requirement for Hanford's low activity waste (LAW) form for shallow land disposal is the chemical durability of the product. A secondary, but still essential specification, is the compressive strength of the material with regards to the strength of the material under shallow land disposal conditions, e.g. the weight of soil overburden and potential intrusion by future generations, because the term "near-surface disposal" indicates disposal in the uppermost portion, or approximately the top 30 meters, of the earth's surface. ${ }^{\S}$

The THOR ${ }^{\circledR}$ Treatment Technologies (TTT) mineral waste form for LAW is granular in nature because it is formed by Fluidized Bed Steam Reforming (FBSR). As a granular product it has been shown to be as durable as Hanford's LAW glass during testing with ASTM C-1285-02 known as the Product Consistency Test (PCT) ${ }^{1,2,3,4}$ and with the Single Pass Flow Through Test (SPFT). ${ }^{4,5,6}$ Hanford Envelope A and Envelope $\mathrm{C}$ simulants both performed well during PCT and SPFT testing and during subsequent performance assessment modeling. ${ }^{5,7}$ This is partially due to the high aluminosilicate content of the mineral product which provides a natural aluminosilicate buffering mechanism ${ }^{2,3,4}$ that inhibits leaching and is known to occur in naturally occurring aluminosilicate mineral analogs. ${ }^{8}$

In order for the TTT Na-Al-Si (NAS) granular mineral product to meet the compressive strength requirements (ASTM C39) for a Hanford waste form, the granular product needs to be made into a monolith or disposed of in High Integrity Containers (HIC's). Additionally, the Hanford intruder scenario for disposal in the Immobilized Low Activity Waste (ILAW) trench is mitigated as there is reduced intruder exposure when a waste form is in a monolithic form.

During the preliminary testing of a monolith binder for TTT's FBSR mineral product, four parameters were monitored:

§ Waste that would decay to acceptable levels within 100 years is defined as Class A or B waste, and institutional controls are believed to be effective at limiting inadvertent intruder risk from these classes of waste. Waste that would decay to acceptable levels for an inadvertent intruder within 500 years was defined as Class $\mathrm{C}$ waste. Class $\mathrm{C}$ waste was envisioned to be segregated from other classes of waste and to be disposed of deeper than Class A and B wastes, and to be disposed of with an intruder barrier that would prevent contact for 500 years. 
- waste loading (not optimized for each waste form tested)

- density

- compressive strength

- durability must not be compromised

- binding agent should not react with the NAS product

- binding agent should not create an unfavorable $\mathrm{pH}$ environment that may cause accelerated leaching.

It is the goal of the present study to survey cementitious waste forms based on Ordinary Portland Cement (OPC), Ceramicrete, and hydroceramic binders by correlating waste loading, density and compressive strength and then determine if these binders affect the product performance in terms of the PCT response. This will be done by making a one-to-one comparison of the PCT response measured on granular NAS mineral product (mixed bed and fines products) with the PCT response of the monolithed NAS product in the different binders.

Future studies may include, refining the above binders, and examining other binders. It is likely that binders formed from kaolin would be most compatible with the chemistry of the THOR ${ }^{\circledR}$ mineral waste form which is made by steam reforming of kaolin and sodium rich wastes. The economics of production on a large scale have yet to be investigated for any of the binders tested.

\subsection{BACKGROUND}

\subsection{Required Low Activity Waste (LAW) Form Durability Testing}

High Level Waste (HLW) produced from over thirty years of reprocessing of nuclear fuels for national defense purposes has been vitrified at the Savannah Rive Site (SRS) since 1996 and at West Valley, NY between 1996 and 2004. A third vitrification facility is currently under construction at the Hanford Reservation in Richland, Washington for HLW. In addition, Hanford is planning to vitrify the Low Activity Waste (LAW) fraction of the HLW. FBSR mineralization and bulk vitrification have been investigated as supplemental technologies to LAW vitrification.

For HLW, Waste Acceptance Product Specifications (WAPS) ${ }^{9}$ and a Waste Compliance Plan (WCP) were developed for the waste form to ensure the acceptance of the product to the federal geologic repository. The WAPS and extensive characterization of the borosilicate glass both before and after production began was required. In order to satisfy the WAPS and WCP product consistency requirement, a leach test was needed which could reliably and easily provide rapid confirmation of the consistency of the glass being produced.

The WAPS specifications most relevant to public health and safety are those relating to release of radionuclides. WAPS Specification 1.3 relates to the ability of the vitrification process to consistently control the final waste form durability, i.e., the stability of the glass against attack by water: 
1.3 Specification for Product Consistency

"The producer shall demonstrate control of waste form production by comparing, either directly or indirectly, production samples to the Environmental Assessment (EA) benchmark glass."10

\subsubsection{Acceptance Criterion}

"The consistency of the waste form shall be demonstrated using the Product Consistency Test (PCT). ${ }^{f}$ For acceptance, the mean concentrations of lithium, sodium and boron in the leachate, after normalizing for the concentrations in the glass, shall each be less than those of the benchmark glass described in the Environmental Assessment for selection of the Defense Waste Processing Facility (DWPF) waste form ${ }^{11}$... One acceptable method of demonstrating that the acceptance criterion is met, would be to ensure that the mean PCT results for each waste type are at least two standard deviations below the mean PCT results of the EA glass."

Lithium, sodium, and boron releases were monitored as nonradioactive indicator(s) that were similar or identical to the maximum radionuclide releases expected for HLW glass because many of the radionuclides were present at concentrations as low as $10^{-8}$ weight $\%$ and thus difficult to measure. For example, in high level borosilicate waste glass, $\mathrm{Tc}^{99}$, present at $\sim 4.1 \times 10^{-4}$ weight $\%$ in the waste form, has been shown ${ }^{12,13,14,15,16,17,18,19,20}$ to be released at the same maximum normalized concentration as boron, lithium, and sodium. $\mathrm{Tc}^{99}$ is the radionuclide released from HLW at a rate higher than all the other radionuclides. Therefore, for borosilicate glass waste forms, the leachates are routinely analyzed for boron, lithium, and sodium if these elements are present at $>1$ mass \% in the glass as an indicator of the maximum radionuclide release, e.g. the $\mathrm{Tc}^{99}$ release.

While relating $\mathrm{Tc}^{99}$ release to $\mathrm{Na}, \mathrm{Li}, \mathrm{B}$ release for a material that leaches congruently is an acceptable practice once the congruent relationship among these elements has been established, this has to be done for each phase present in a glass-ceramic or mineral waste forms because each phase leaches at a different rate, e.g. the multiphase waste form leaches incongruently. ${ }^{\dagger}$ For multiphase materials like glass-ceramics and mineral waste forms, the most important elements to be analyzed in the leachate are those that represent the maximum dissolution of the

f C.M. Jantzen, N.E. Bibler, D.C. Beam, W.G. Ramsey, and B.J. Waters. "Nuclear Waste Product Consistency Test Method Version 5.0,” U.S. DOE Report WSRC-TR-90-539, Rev. 2 (January 1992).

* Congruent dissolution of a waste form, like glass, is the dissolving of species in their stoichiometric amounts. For congruent dissolution, the rate of release of a radionuclide from the waste form is proportional to both the dissolution rate of the waste form and the relative abundance of the radionuclide in the waste form. Thus for borosilicate glass ${ }^{99} \mathrm{Tc}$ has been shown to be released at the same rate, congruently, as Na, Li and B.

$\dagger \quad$ Incongruent dissolution of a waste form means that some of the dissolving species are released preferentially compared to others. Incongruent dissolution is often diffusion-controlled and can be either surface reactionlimited under conditions of near saturation or mass transport-controlled. Preferential phase dissolution, ionexchange reactions, grain-boundary dissolution, and dissolution-reaction product formation (surface crystallization and recrystallization) are among the more likely mechanism of incongruent dissolution, which will prevail, in a complex polyphase ceramic waste form. 
radionuclides from the waste form. Elements that are not sequestered in precipitates that participate in surface alteration reactions, and elements that are not solubility limited are good indicators of waste form durability. In the case of a multi-phase glass or mineral waste form it may be important to analyze for elements from each significant phase present as these waste forms leach incongruently. Extensive testing ${ }^{12-20}$ of any glass or glass ceramic waste form must be performed in order to determine what these elements are unless the radionuclide release (or surrogate radionuclide release) is measured.

The initial basis for the DWPF Product Consistency Test (PCT) was derived from a comparison of crushed glass durability tests from the Materials Characterization Center (MCC), the American Society for Testing Materials (ASTM), and Corning Glass Works (CGW). The features of each test that had the potential to optimize the following criteria were considered during PCT development:

- sensitivity of the test method to glass composition and homogeneity

- minimum time necessary to demonstrate product quality

- ease of sample preparation for radioactive glass

- precision of the test results

- acceptance by waste form developers and repository projects

The PCT was developed between 1987 and 1994 when it became an ASTM standard for HLW borosilicate glass. In 1997 and 2002 the scope was broadened to include hazardous waste glasses, mixed waste glasses, and glass ceramics. Based on extensive testing of glasses and glass-ceramics, including a seven-laboratory round robin, and confirmatory testing with radioactive samples, the PCT has been shown to be reproducible, to distinguish between glasses of different durability and homogeneity, to yield reliable results rapidly, and to be amenable to being performed in shielded cell facilities with radioactive samples. Additional PCT testing of ceramic waste forms has occurred since 2002 and application of this test to ceramic waste forms is currently being considered.

The use of the PCT test protocol for HLW vitrified waste was applied at Hanford for testing the consistency of both the Hanford HLW vitrified waste and the immobilized LAW waste form. ${ }^{21}$ The PCT is used to determine the waste form leaching and durability in conjunction with ANSI/ANS-16.1 ${ }^{22}$ and the PCT is used for determining waste form stability. ${ }^{21}$ The Hanford contract $^{23}$ and the ILAW Product Compliance Plan specify the following:

"The normalized mass loss of sodium, silicon, and boron shall be measured using a seven day product consistency test run at $90^{\circ} \mathrm{C}$ as defined in ASTM C1285-97.

The test shall be conducted with a glass to water ratio of 1 gram of glass (-100 +200 mesh) per 10 milliliters of water. The normalized mass loss shall be less than 2.0 grams $/ \mathrm{m}^{2}$. Qualification testing shall include glass samples subjected to representative waste form cooling curves. The product consistency test shall be conducted on waste form samples that are statistically representative of the production glass." 
In addition, the Hanford contract ${ }^{23}$ requires durability testing by the Vapor Hydration Test (VHT) as follows:

"The glass corrosion rate shall be measured using at least a seven day vapor hydration test run at $200^{\circ} \mathrm{C}$ as defined in the DOE concurred upon ILAW Product Compliance Plan. The measured glass alteration rate shall be less than 50 grams $/\left(\mathrm{m}^{2}\right.$ day $)$. Qualification testing shall include glass samples subjected to representative waste form cooling curves. The vapor hydration test shall be conducted on waste form samples that are representative of the production glass."

Because the VHT test interpretation for waste forms other than glass has not been investigated and the results of this test are used solely for engineering calculations of contaminant release, ${ }^{21}$ the PCT durability test was used in this study as the screening test for the FBSR monoliths.

\subsection{Compressive Strength}

In the 1983 (Revision 0) of 10 CFR 61.56(b)(1) regarding the stability of a waste form for shallow land burial, it is stated that "a structurally stable waste form will generally maintain its physical dimensions and form under expected disposal conditions (45 feet) such as weight of overburden and compaction equipment..." Assuming a cover material density of $120 \mathrm{lbs} / \mathrm{ft}^{3}$, a minimum compressive strength criterion of 50 psi after curing for minimum of 28 days was established, although it was also stated that the waste forms should achieve the "maximum practical compressive strength" not just the "minimum acceptable compressive strength." Later, the burial depth was increased to 55 feet and the minimum compressive strength criterion was increased to 60 psi after curing for a minimum of 28 days.

In the early 1990's the compressive strength criterion was re-evaluated. Because OPC mortars (cement, lime, silica sand and water) are capable of achieving compressive strengths of 5000$6000 \mathrm{psi}$, the minimum compressive strength for a waste form for shallow land burial was increased to 500 psi after curing for a minimum of 28 days. The rationale was that low-level radioactive waste material constituents are not capable of providing the physical and chemical functions of silica sand in a cement mortar and so a reasonable compressive strength was $1 / 10^{\text {th }}$ that of a cement made with silica sand. ${ }^{24}$

The Hanford contract ${ }^{23}$ for LAW specifies the following:

"The mean compressive strength of the waste form shall be determined by testing representative non-radioactive samples. The compressive strength shall be at least 3.45E6 Pa (500 psi) when tested in accordance with ASTM C39/C39M-99 or an equivalent testing method"

Because OPC mortars achieve $\sim 75 \%$ of their 28 day strength in 7 days of curing, ${ }^{25}$ samples cured for only 7 days were compression tested in this study with the assumption that any monolith cured for 7 days that would pass the compression test would, therefore, pass after a total of 28 days of curing under the same conditions. 


\subsection{Waste Loading}

For disposal of FBSR wastes at Hanford in Richland, WA there is an additional specification that governs the waste loading. Waste loading for Hanford LAW wastes are specified in terms of the amount of $\mathrm{Na}_{2} \mathrm{O}$ from the waste that can be accommodated in the waste form. The most stringent of these criteria is for Envelope A waste. The specification (Section 2.2.2.2 of the Product Requirements) ${ }^{23}$ states:

"Waste Loading: The loading of waste sodium from Envelope A in the ILAW glass shall be greater than 14 weight percent based on $\mathrm{Na}_{2} \mathrm{O}$. The loading of waste sodium from Envelope B in the ILAW glass shall be greater than 3.0 weight percent based on $\mathrm{Na}_{2} \mathrm{O}$. The loading of waste sodium from Envelope $\mathrm{C}$ in the ILAW glass shall be greater than 10 weight percent based on $\mathrm{Na}_{2} \mathrm{O}$."

Because all of the $\mathrm{Na}_{2} \mathrm{O}$ in the Hanford LAW Envelope A waste made during pilot scale testing in $2003-2004^{2,3}$ contained $20.87 \mathrm{wt} \% \mathrm{Na}_{2} \mathrm{O}$, all of which came from the waste, any monoliths developed must not dilute the product concentration to less than $14 \mathrm{wt} \% \mathrm{Na}_{2} \mathrm{O}$. Therefore, the FBSR LAW Envelope A waste loading must be $\geq 67 \mathrm{wt} \%$, the Envelope B FBSR waste loading must be $\geq 14 \mathrm{wt} \%$, and the Envelope C FBSR waste loading must be $\geq 47 \mathrm{wt} \%$.

\subsection{QUALITY ASSURANCE}

The waste form fabrication and testing conducted at the Savannah River National Laboratory (SRNL) was conducted in accordance with DOE/RW-0214, DOE/RW-0333P, and ASME NQA1 based quality assurance programs. The Ceramicrete was fabricated at Argonne National Laboratory (ANL) who owns the patent(s) on the Ceramicrete technology. The initial hydroceramic formulation came from researchers at the Pennsylvania State University who own the patent(s) on the hydroceramic technology. Two of the five OPC formulations came from R.J. Lee testing of TTT monoliths. The data is recorded in the following notebooks: WSRCNB-2004-00082 and WSRC-NB-2006-00072.

\subsection{EXPERIMENAL}

\subsection{Initial Waste Characterization}

Between 2003 and 2004 the durability of the mineral waste forms produced during three different pilot scale FBSR demonstrations at the Science Applications International Corporation (SAIC) Science and Technology Applications Research (STAR) facility in Idaho Falls, ID were evaluated. ${ }^{2,3}$ The waste NAS mineral waste forms produced (Table 1) included the granular bed material produced in the Denitration Mineralizing Reactor (DMR) after steady state operations were achieved and the finer mineral material from the filter hereafter referred to as the filter 
fines. Bed material from a 2003 and a 2004 STAR pilot scale campaign ${ }^{26,27}$ with Idaho National Laboratory (INL) Sodium Bearing Waste (SBW) and bed and filter fines from a third pilot scale demonstration $^{28}$ with a Hanford Low Activity Waste (LAW) Envelope A waste simulant had previously been characterized and durability tested at SRNL by the ASTM C1285 procedure. ${ }^{2,3}$ The type of simulated wastes tested and the duration of each test are given in Table 1.

Small portions of the SBW and LAW bed and filter fines products were available from the pilot scale campaigns in Table 1 and some intermediate bed product materials were also available for monolith formation and testing. All of the bed products (some of which contained $\mathrm{Al}_{2} \mathrm{O}_{3}$ startup bed material) and fines were combined and mixed. Many still had unreacted charcoal in them. Because the TTT flowsheet currently has a second reformer known as the Carbon Reduction Reformer (CRR), it was decided to roast the charcoal out of the product before durability testing as had been done in the durability testing of the granular FBSR product. ${ }^{2,3}$ This also eliminates charcoal content as a variable because previous testing had indicated that the charcoal content of the bed and fines has an impact on the measured surface area. The surface area of any charcoal particles is irrelevant to product performance but would, in this case positively impact PCT results as the increased surface area from the charcoal would result in reduced PCT releases, so eliminating the charcoal provides more conservative PCT results. Because the charcoal is not part of the actual mineral product (i.e., inert in terms of the PCT response and will not be present due to the CRR), a surface area to volume ratio that included charcoal would underestimate PCT release. Therefore, all analyses and all durability results are reported in this study on a charcoal free basis. This also facilitates comparison to the results presented in References 2 and 3, which are also reported on a charcoal free basis.

Table 1 Pilot Scale FBSR Samples Tested in 2003-2004 at the SAIC STAR Facility

\begin{tabular}{|c|c|c|c|c|}
\hline Demonstration & $\begin{array}{c}\text { Sample } \\
\text { ID }\end{array}$ & $\begin{array}{c}\text { Total } \\
\text { Operating } \\
\text { Time (TOT) }\end{array}$ & $\begin{array}{c}\text { Bed } \\
\text { Turnover } \\
(\%)\end{array}$ & Description \\
\hline \multirow{3}{*}{$\begin{array}{l}\text { July } 2003 \\
\text { SBW [26] }\end{array}$} & Bed 260 & $82 \mathrm{hrs}$ & Unknown $^{\dagger}$ & Dynamic bed product \\
\hline & Bed 272 & $82 \mathrm{hrs}$ & Unknown $^{\dagger}$ & Dynamic bed product \\
\hline & Bed 277 & $82 \mathrm{hrs}$ & Unknown $^{\dagger}$ & Dynamic bed product \\
\hline \multirow{3}{*}{$\begin{array}{c}\text { August } 2004 \\
\text { LAW [28] }\end{array}$} & Bed 1103 & $\begin{array}{c}55 \mathrm{hrs} \text { and } 30 \\
\min \end{array}$ & 97.4 & Dynamic bed product \\
\hline & Bed 1104 & $\begin{array}{c}55 \text { hrs and } 30 \\
\text { min }\end{array}$ & 99.7 & Final bed product \\
\hline & $\begin{array}{c}\text { Fines } \\
1125\end{array}$ & $\begin{array}{c}55 \text { hrs and } 30 \\
\text { min }\end{array}$ & 100 & Final filter fines \\
\hline $\begin{array}{c}\text { October } 2004 \\
\text { SBW [27] }\end{array}$ & Bed 1173 & 100 hours & 92 & Final bed product \\
\hline
\end{tabular}

Carbon was removed from the mixed bed and fines products by heating the samples to $525^{\circ} \mathrm{C}$ overnight. This temperature was chosen because it is high enough to oxidize (remove) the carbon, but not high enough to change the composition or the phase assemblages. This is the 
temperature specified in a United States Geological Survey (USGS) procedure ${ }^{29}$ for carbon removal in preparation for the analysis of coal combustion by-products. Samples before and after carbon removal by this method were examined by Pareizs ${ }^{2}$ and Jantzen $^{3}$ to verify that the phase assemblages had not changed.

The samples had been mixed together in a large container before roasting the carbon out and again after roasting the carbon out. The mixed SBW/LAW NAS mineral products were analyzed by X-ray Diffraction (XRD) to verify the phase composition of the amalgamated material being monolithed. In order to determine the chemical content of the mixture, solid samples were digested with a lithium tetraborate fusion at $1000^{\circ} \mathrm{C}$ followed by a hydrochloric acid uptake $\mathrm{e}^{30,31}$. The resulting solutions were analyzed by Inductively Coupled Plasma Emission Spectroscopy (ICP-ES) for Ag, Al, Ca, Cd, Cr, Cs, Cu, Fe, K, La, Mg, Mn, Na, Ni, P, Pb, S, Si, and Ti and Inductively Coupled Plasma Mass Spectroscopy (ICP-MS) for Cs and Re. Anion content was determined from a sodium peroxide/sodium hydroxide fusion at $600^{\circ} \mathrm{C}$ followed by a water uptake $^{32}$. The resulting solutions were analyzed by Ion Chromatography (IC) for $\mathrm{NO}_{3}^{-}, \mathrm{F}^{-}$, and $\mathrm{Cl}^{-}$.

\subsection{Cement Monoliths}

Cement monoliths were fabricated from Type II Portland Cement because this is the OPC type used in previous testing at R.J. Lee, Corp. It should be noted that Type I and Type II OPC are very similar ${ }^{25}$ and either could have been used for the formulations. Two formulations were fabricated to represent the same admixtures tested by R.J. Lee, Corp. One cement monolith of each waste loading given in Table 2 was fabricated. Formulations D and E were made with precipitated silica (representing a chemically pure pozzolanic material such as fly ash or slag) to see if the overall durability of the cement monoliths would improve with excess silica present to react with the $\mathrm{CaOH}$ formed by the hydration of OPC. Slag and/or fly ash were not chosen as pozzolanic additives as they contain large concentrations of impurities that may have compromised the durability testing of the cement monoliths

All cement monoliths were set in Teflon ${ }^{\circledR}$ molds that had 2" x 2" chambers (Figure 1). Teflon ${ }^{\circledR}$ was chosen so that a mold release would not have to be used since it could have compromised the durability and/or compression testing. All cement monoliths were set for 7 days in air at ambient temperature before compression testing.

Table 2. SRNL Cement Monolith Formulations

\begin{tabular}{|c|c|c|c|c|c|}
\hline Monolith Constituents & $\begin{array}{c}\text { CEMENT } \\
\text { SRNL A }\end{array}$ & $\begin{array}{c}\text { CEMENT } \\
\text { SRNL B }\end{array}$ & $\begin{array}{c}\text { CEMENT } \\
\text { SRNL C }\end{array}$ & $\begin{array}{c}\text { CEMENT } \\
\text { SRNL D }\end{array}$ & $\begin{array}{c}\text { CEMENT } \\
\text { SRNL E }\end{array}$ \\
\hline Precipitated $\mathrm{SiO}_{2}$ & NO & NO & NO & YES & YES \\
\hline $\begin{array}{c}\text { FBSR Product Loading } \\
\% \text { dry basis }\end{array}$ & 84 & 87 & 80 & 80 & 81 \\
\hline
\end{tabular}


WSRC-STI-2006-00033

Revision 1
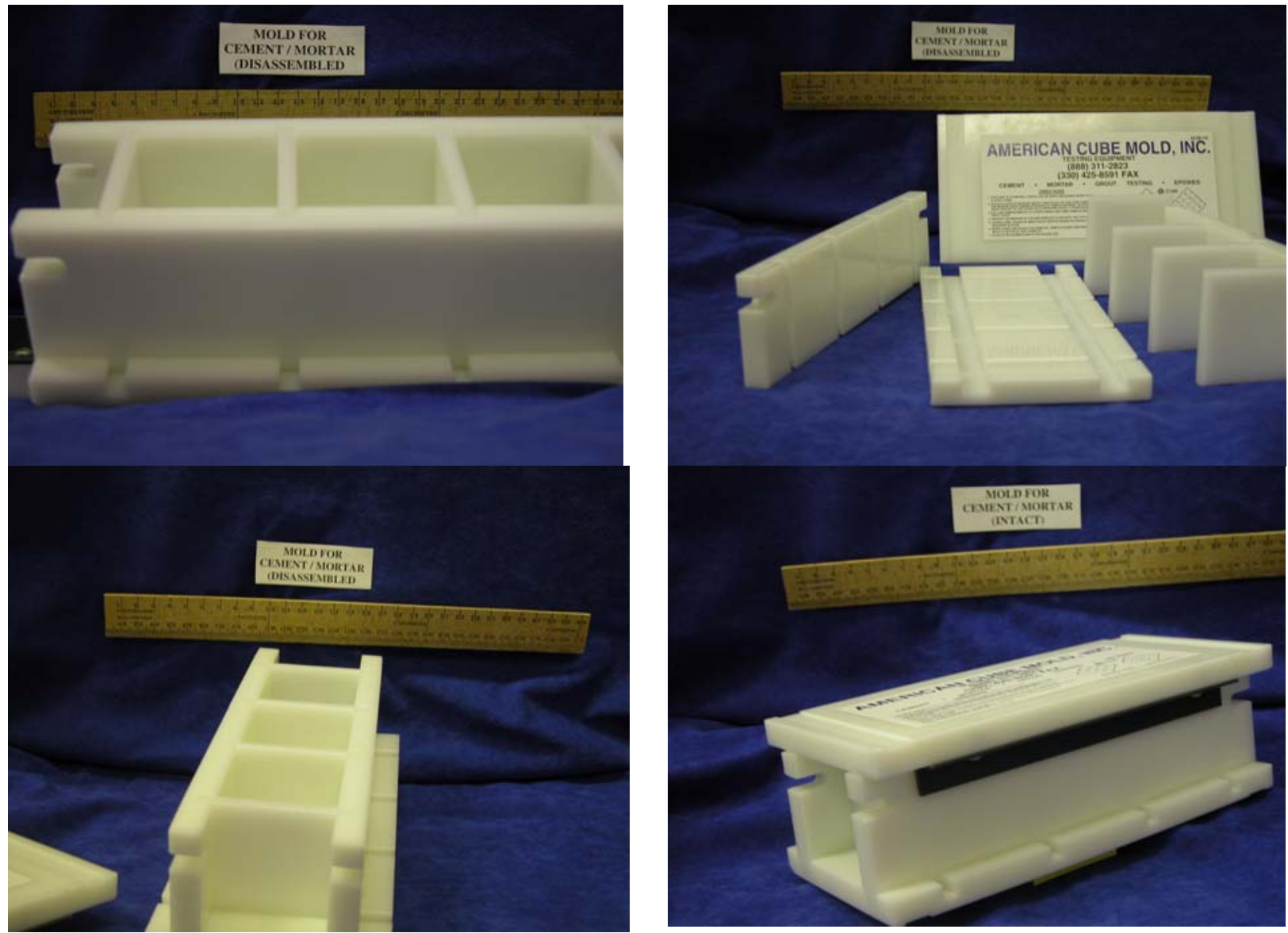

Figure 1. Teflon ${ }^{\circledR}$ molds used in cement and hydroceramic monolith formation. 

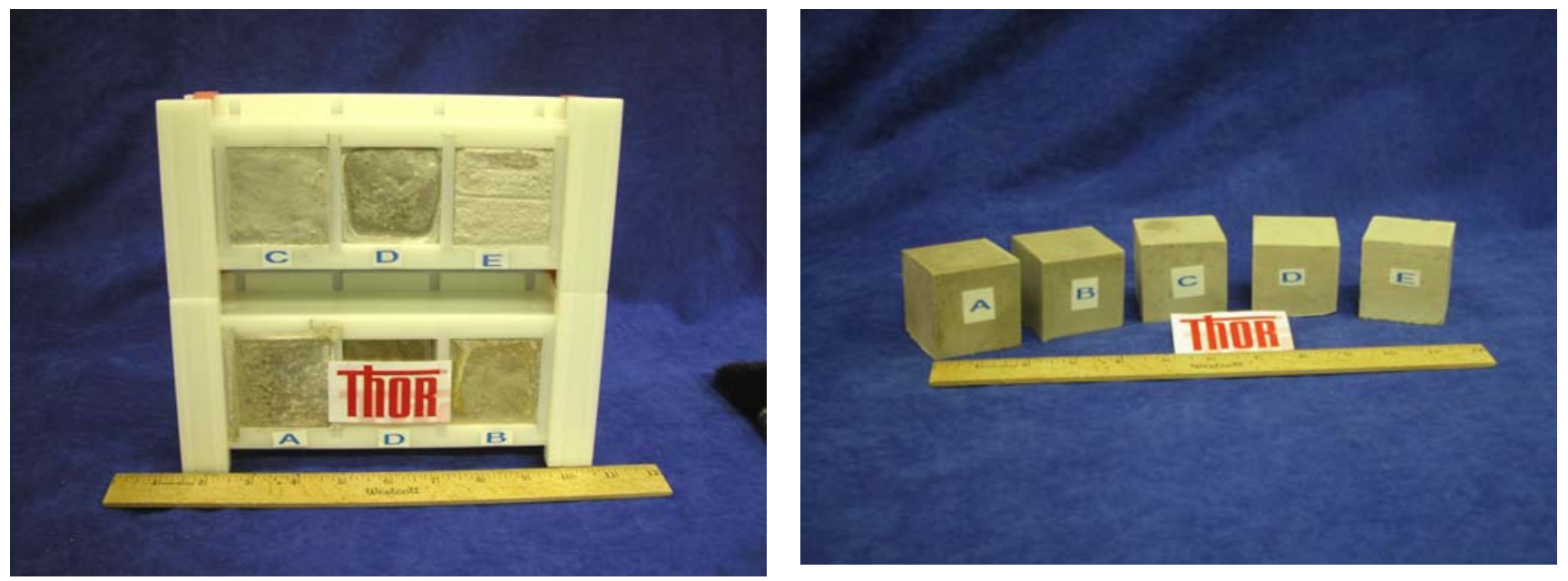

Figure 2. Cement monoliths after setting for 7 days and before compression and durability testing.

\subsection{Ceramicrete Monoliths}

Ceramicrete is a blend of $\mathrm{MgO}$ and monopotassium phosphate $\left(\mathrm{KH}_{2} \mathrm{PO}_{4}\right)$. The blend is mixed with a stoichiometric amount of water according to the formulation:

$$
\mathrm{MgO}+\mathrm{KH}_{2} \mathrm{PO}_{4}+5 \mathrm{H}_{2} \mathrm{O} \rightarrow \mathrm{MgKPO}_{4} \bullet 6 \mathrm{H}_{2} \mathrm{O}
$$

The reaction product on the right hand side of the equation is Ceramicrete, a rapid setting phosphate ceramic. ${ }^{33}$ Ceramicrete monoliths were made at Argonne National Laboratory (ANL) at an FBSR loading of $35.7 \mathrm{wt} \%$.

The monoliths were cured at ambient temperature for two weeks, unmolded, the ends polished, and then shipped to SRNL for durability testing. The samples were very dense, beige in color, and smooth on surface except for few air pockets on the sides of the samples due to air entrapment. According to ANL personnel these pockets could have been avoided by vibrating the slurry in the mold after transferring the slurry into the molds. The open porosity of the samples was evaluated by ANL using a water immersion method. It was negligible in all cases. In order to evaluate the volume change after solidification, ANL measured the packed powder density and determined that at $33.3 \mathrm{wt}$.\% loading a volume reduction of $\sim 25 \%$ was achieved. 

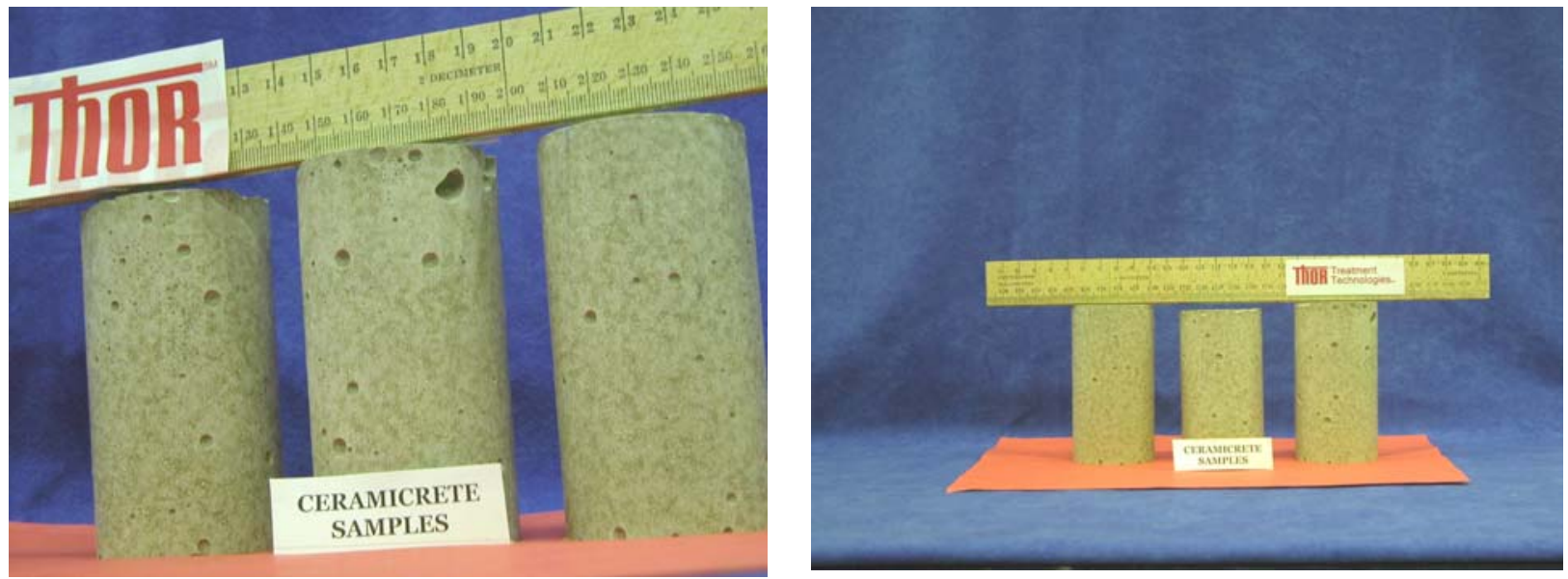

Figure 3. Ceramicrete monoliths before Compression and durability testing.

\subsection{Hydroceramic Monoliths}

Hydroceramics are made by the solidification of $\mathrm{NaOH}$ or denitrated high sodium waste with $\mathrm{NaOH}$ and metakaolin clay. ${ }^{34}$ Metakaolin clay is kaolin clay that has been heat treated at $\geq 700^{\circ} \mathrm{C}$ to render it amorphous and anhydrous and thus very reactive. The samples which are mixed to a "bread dough" consistency, extruded into a mold, and cured in steam. Reference 34 recommends a cure at $40^{\circ} \mathrm{C}$ in a $100 \%$ humidity chamber overnight in a mold. The sample is then demolded and cured for an additional 24 hours at $90^{\circ}$ in a steam saturated atmosphere (Teflon ${ }^{\circledR}$-lined Parr bombs). The curing ensures that the $\mathrm{NaOH}$ and metakaolin react to form zeolite mineral phases which are the hydroceramic analogues of the steam reformer feldspathoid minerals.

In this study the $50 \%, 60 \%$ and 80 FBSR product loadings on a dry basis were tested. The first three waste loadings were set in the Teflon ${ }^{\circledR}$ molds shown in Figure 1 and cured in a humidity chamber overnight at $40^{\circ} \mathrm{C}$. The samples were then unmolded and cured at $40^{\circ} \mathrm{C}$ in steam for an additional 24 hours before compression testing. These samples are hereafter referenced as "Hydroceramics Set 1." These samples produced insufficient strength in 7 days.

A second set of hydroceramic blocks were made (Hydroceramics Set 2) and set in steel molds so they could be cured at higher temperatures, e.g. $70^{\circ} \mathrm{C}$. These samples produced insufficient strength in 6 days. The change to steel molds was necessitated because the hydroceramics were sticking to the Teflon ${ }^{\circledR}$ molds and because higher curing temperatures were needed to achieve a set in 6-7 days, lower temperatures are likely acceptable at longer curing times but this needs to be optimized. 
A third set of hydroceramic blocks (Hydroceramics Set 3) were made in duplicate and cured overnight at $90^{\circ} \mathrm{C}$ in steel molds at $100 \%$ humidity for 7 days at $90^{\circ} \mathrm{C}$ in a humidity chamber at $100 \%$ relative humidity before compression testing.

Hydroceramics Set 1 was used for durability testing even though these monoliths did not meet the final compressive strength requirement. This was done under the assumption that the binder effects from the clay and $\mathrm{NaOH}$ added to form the hydroceramics would be the same or worse for a monolith incompletely reacted than one completely reacted.

A summary of all the formulations and curing conditions are given in Table 3. Pictures of the hydroceramic blocks set at $40^{\circ} \mathrm{C}$ (Set 1) and $70^{\circ} \mathrm{C}$ (Set 2) for 7 days are shown in Figure 5 and Set 3 cured at $90^{\circ} \mathrm{C}$ for 7 days are shown in Figure 6.

\subsection{Monolith Characterization}

Since the FBSR product and the binders were well mixed before each was cured and all of the sample was used to make each monolith, broken pieces of each monolith were considered to be representative of the entire block. The broken pieces were analyzed by the same dissolution and ICP-ES and ICP-MS methods outlined in Section 4.1. Weight loss to determine the water content was determined after heating $700^{\circ} \mathrm{C}$ for 8 hours.

The cement, Ceramicrete, and hydroceramics were also analyzed by X-ray Diffraction (XRD) to see if the monolithing agents had reacted with the FBSR product.
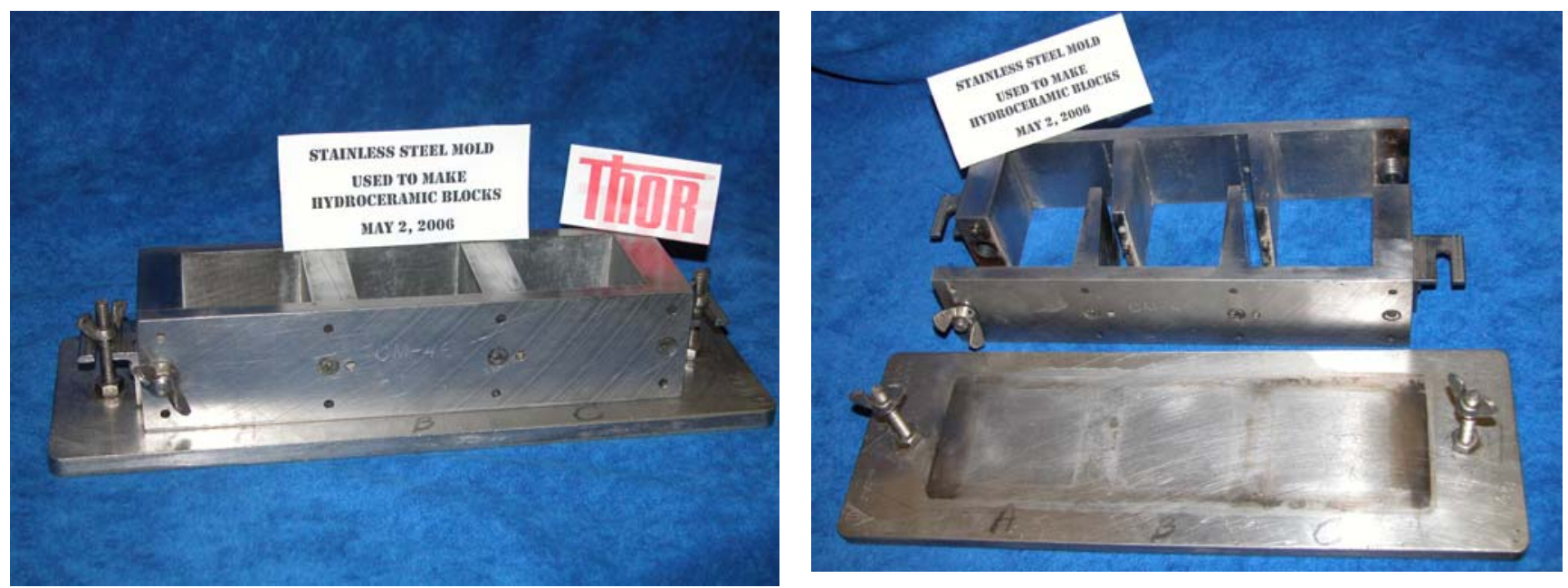

Figure 4 . Stainless steel molds used in cement and hydroceramic monolith formation. 
Table 3. SRNL Hydroceramic Monolith Formulations and Curing Conditions

\begin{tabular}{|c|c|}
\hline $\begin{array}{l}\text { Hydroceramic } \\
\text { Identification }\end{array}$ & $\begin{array}{l}\text { FBSR Product } \\
\% \text { dry basis }\end{array}$ \\
\hline \multicolumn{2}{|c|}{ SET 1 - CURED AT $40^{\circ} \mathrm{C}$ in Teflon $\AA$ Molds } \\
\hline $\mathrm{A}$ & 50 \\
\hline $\mathrm{B}$ & 60 \\
\hline $\mathrm{C}$ & 80 \\
\hline \multicolumn{2}{|c|}{ SET $2-$ CURED AT $70^{\circ} \mathrm{C}$ in Steel Molds } \\
\hline $\mathrm{A}-2$ & 50 \\
\hline B-2 & 60 \\
\hline $\mathrm{C}-2$ & 80 \\
\hline \multicolumn{2}{|c|}{ SET 3 - CURED AT $90^{\circ} \mathrm{C}$ in Steel Molds } \\
\hline $\mathrm{A}-3-\mathrm{a}$ & 50 \\
\hline$A-3-b$ & 60 \\
\hline B-3-a & 80 \\
\hline B-3-b & 50 \\
\hline C-3-a & 60 \\
\hline $\mathrm{C}-3-\mathrm{b}$ & 80 \\
\hline
\end{tabular}
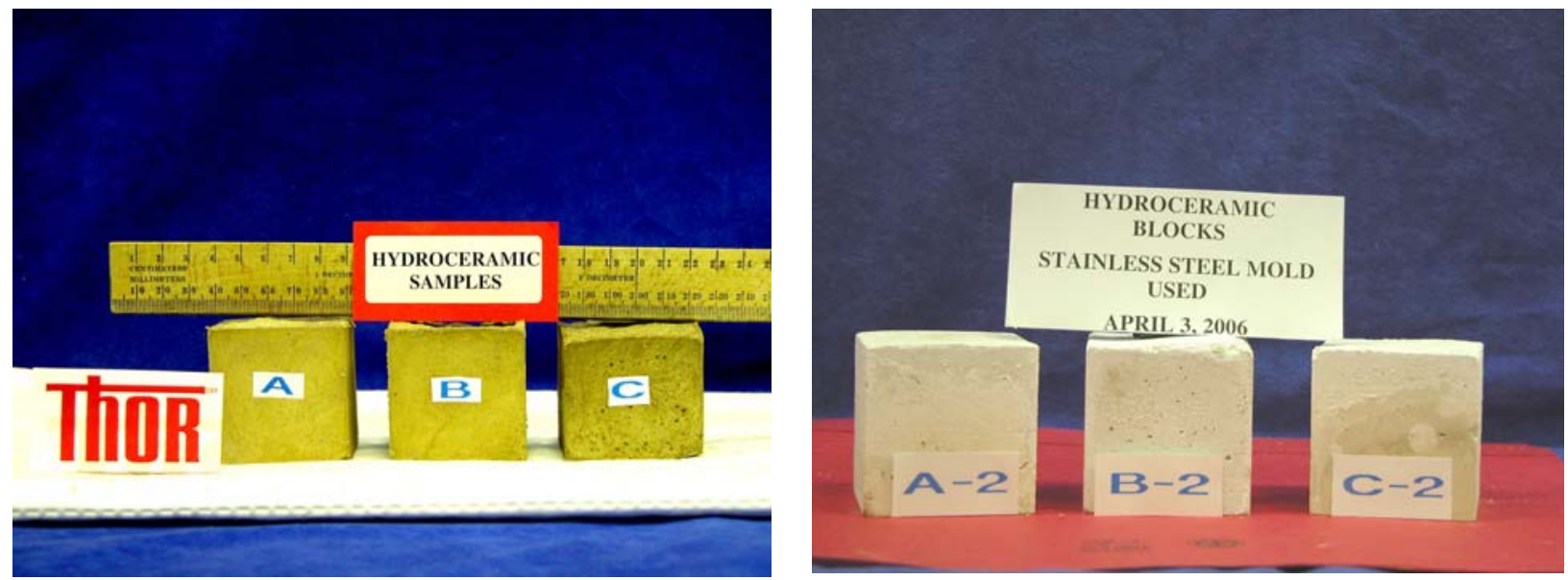

Figure 5. Hydroceramic blocks Set 1 (left) and Set 2 (right). 


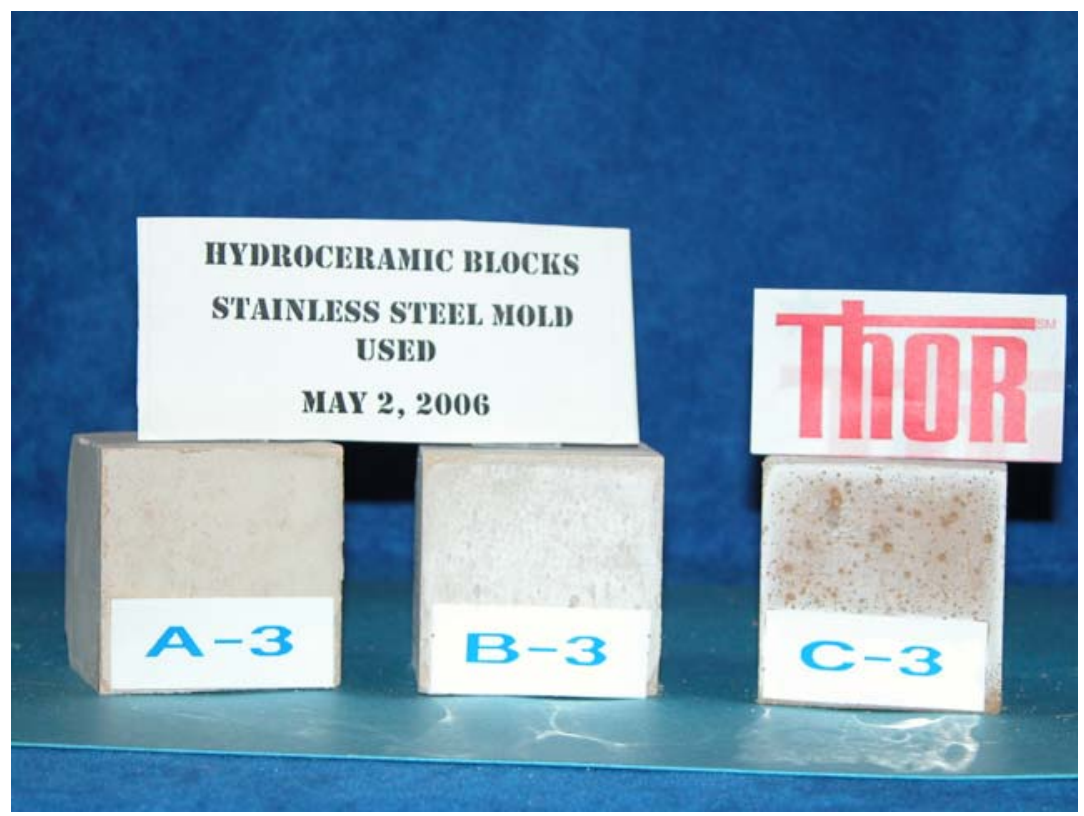

Figure 6. Hydroceramic blocks Set 3.

\subsection{Density and Compression Testing}

The 2" x 2" square blocks of concrete and hydroceramics were compression tested using ASTM C 109-02 and the Ceramicrete cylinders were compression tested using ASTM C39-04A (Figure 7). All compression testing was performed at SRS by William Myhre of Washington Savannah River Company. Comparative compression testing with ASTM C39 was available for the Ceramicrete monoliths from ANL.

The density of each monolith was calculated from the geometric dimensions of each monolith in centimeters and the measured weight in grams measured by SRNL. Density results are tabulated in $\mathrm{g} / \mathrm{cc}$. Comparative density measurements were available for the Ceramicrete monoliths from ANL. 

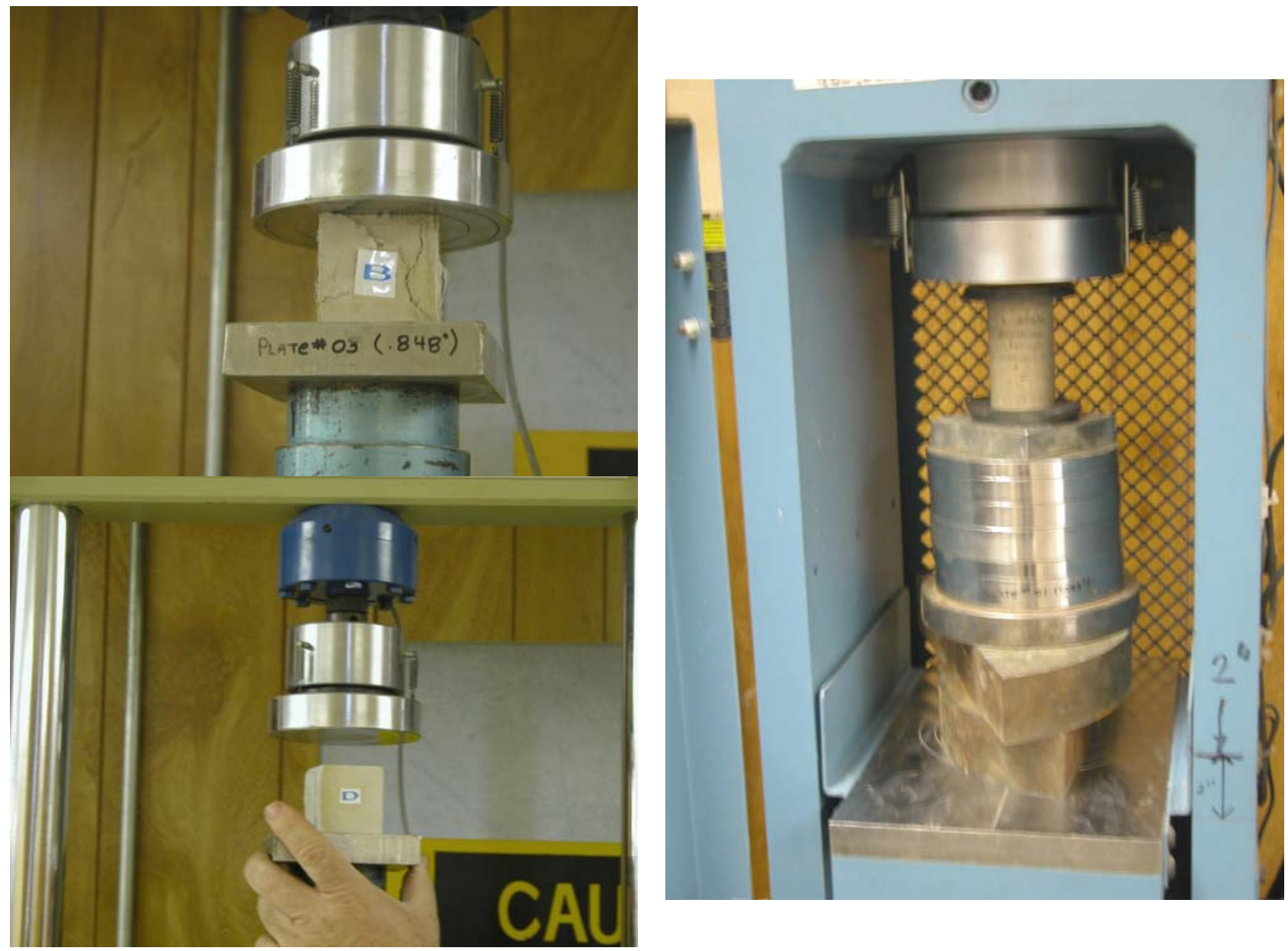

Figure 7. Compression testing by ASTM C109-02 (left upper and lower) and ASTM C39-04A (right).

\subsection{Durability Testing}

The chemical durability of the steam reformer pilot scale products was determined using ASTM procedure C $1285-02^{36}$. The monolithed samples were ground and sized between -100 and +200 mesh (74 $\mu \mathrm{m}$ to $149 \mu \mathrm{m})$, the same size fraction used to express glass waste form performance and used to test the granular FBSR bed and fines products. To remove the electrostatic fines, the sized material was washed six times with $100 \%$ ethanol. Water was not used for washing for fear of removing any water soluble phases prior to leaching as cautioned by the ASTM C1285-02 procedure.

For all samples, ASTM Type I water ${ }^{35}$ was used as the leachant, a constant leachant to sample ratio of $10 \mathrm{~cm}^{3} / \mathrm{g}$ or $0.01 \mathrm{~L} / \mathrm{g}$ ( $\mathrm{V}$ in equations 1 and 2 below) was used, the test temperature was $90^{\circ} \mathrm{C}$, and the test duration was seven days. The test temperature and 7 day test duration are the nominal test conditions used for testing glass waste form performance, e.g. PCT-A. 
The Product Consistency Test (PCT) results can be expressed as a normalized concentration $\left(\mathrm{NC}_{\mathrm{i}}\right)$ which have units of $\mathrm{g}_{\text {waste form }} / \mathrm{L}_{\text {leachant }}$, or as a normalized release $\left(\mathrm{NL}_{\mathrm{i}}\right)$ in $\mathrm{g}_{\text {waste form }} / \mathrm{m}^{2}$, or as a normalized rate $\left(\mathrm{NR}_{\mathrm{i}}\right)$ in $\mathrm{g}_{\text {waste form }} / \mathrm{m}^{2}$.day where " $\mathrm{i}$ " is the chemical element of interest. Expression of the PCT test response as $\mathrm{NL}_{\mathrm{i}}$ or $\mathrm{NR}_{\mathrm{i}}$ necessitates the use of the surface area (SA) of the sample releasing species "i $i$ " and the volume (V) of the leachant being used which is expressed as the SA/V ratio. Examples of the calculations are given in Equation 1 and 2

$$
N L_{i}=\frac{c_{i}(\text { sample })}{f_{i} \cdot(S A / V)}
$$

where $\quad N L_{i}$ is the normalized release $\left(\mathrm{g}_{\text {waste form }} / \mathrm{m}^{2}\right)$

$c_{i}$ (sample) is the concentration of element $i$ in the leachate solution $\left(\mathrm{g}_{\mathrm{i}} / \mathrm{L}\right)$

$f_{i}$ is the fraction of element $i$ in the unleached waste form (unitless).

and

$$
N R_{i}=\frac{c_{i}(\text { sample })}{f_{i} \cdot(S A / V) \cdot t}
$$

where $\quad \mathrm{NR}_{\mathrm{i}}$ is the normalized release rate $\left(\mathrm{g}_{\text {waste form }} / \mathrm{m}^{2}\right.$.day)

$c_{i}$ (sample) is the concentration of element " $\mathrm{i}$ " in the leachate solution $\left(\mathrm{g}_{\mathrm{i}} / \mathrm{L}\right)$

$f_{i}$ is the fraction of element " $\mathrm{i}$ " in the unleached waste form (unitless)

$S A / V$ is the surface area of the final waste form divided by the leachate volume $\left(\mathrm{m}^{2} / \mathrm{L}\right)$

$t$ is the time duration of test (days).

In order to calculate $\mathrm{NL}_{\mathrm{i}}$, the units used to express LAW glass durability, the surface area of the material being tested must either be calculated (ASTM C 1285, Appendix $\mathrm{XI}^{36}$ ) or measured. In this study the waste form SA/V ratio was determined two ways. In the first method, the surface area was calculated using the average particle size diameter as determined from the geometric surface area and the monolith bulk density as is done for homogeneous vitreous waste forms.

$$
S A / V_{\text {calc }}=\frac{6}{\rho \cdot d \cdot V}
$$

where $S A / V_{\text {calc }}$ is the calculated surface area to volume ratio based on the average particle diameter and the waste form monolith density

$d$ is the average particle density $(\mathrm{m})$

$\rho$ is the waste form particle density $\left(\mathrm{g} / \mathrm{m}^{3}\right)$

$V$ is the volume of leachant $V$ per $\mathrm{g}$ of waste form $(\mathrm{L} / \mathrm{g})$.

The second method for SA/V determination involves a measurement of the surface area by the BET method ${ }^{37}$ recommended by $\mathrm{McGrail}^{5}$. In this method, the amount of an inert gas that condenses on a powdered sample is measured at a temperature near the boiling point of the gas. The amount of gas condensed on the sample is measured by the pressure change in the system upon exposure to the sample. All open pores, inclusions, irregularities, etc. penetrable by the 
inert gas (nitrogen for this work) are accounted for in the surface area. This surface area may be different from the surface area penetrable by water during a leaching test ${ }^{38}$ but is the best measurement available. The $\mathrm{SA} / \mathrm{V}$ ratio is simply calculated by dividing the measured BET surface area by the leachant volume:

$$
S A / V_{B E T}=\frac{S A_{B E T}}{V}
$$

where $S A / V_{B E T}$ is the surface area to volume ratio determined from a BET measurement of waste form surface area $\left(\mathrm{m}^{2} / \mathrm{L}\right)$

$S A_{B E T}$ is the specific surface area as measured by BET $\left(\mathrm{m}^{2} / \mathrm{g}\right)$.

\subsection{RESULTS}

\subsection{Initial Waste Characterization}

Small portions of the SBW and LAW bed and filter fines products from the pilot scale campaigns in Table 1 and some intermediate bed and fines product materials were combined and mixed for monolith fabrication and testing. All of the unreacted carbon had been roasted out of the products since the TTT flowsheet currently has a second reformer to remove or minimize carbon carryover into the product. The composite bed and fines materials were characterized by the methods outlined in Section 4.1. The analytic methods used were the same as those used to characterize the individual bed and fines products as outlined in Reference 2.

The analyses of the composite INL STAR campaign products to be used for the formation of monoliths were analyzed in this study and the results are given in Table 4 on an oxide basis. For comparison the average analysis of the 2003 SWB bed products (bed 260, bed 272, and bed 277), the average analysis of the 2004 SBW bed products (bed 1173) and the average analysis of the 2004 LAW bed products and fines (bed 1103, bed 1104 and fines 1125) are also tabulated in Table 4. When the analysis of the averaged 2003 SBW, 2004 SBW, and 2004 LAW FBSR products are compared to the composite in this study it is obvious that the $\mathrm{Al}_{2} \mathrm{O}_{3}$ content is very high in the composite to be used to make monoliths indicating that there is a significant contribution of this material that is unreacted startup bed $\mathrm{Al}_{2} \mathrm{O}_{3}$. This is confirmed by the X-ray Diffraction spectra of the composite waste tested in this study which indicated that $\mathrm{Al}_{2} \mathrm{O}_{3}$ from the startup bed is a major component phase along with bed and fines materials containing nepheline $\left(\mathrm{Na}_{6.8} \mathrm{Al}_{6.3} \mathrm{Si}_{9.7} \mathrm{O}_{32}\right)$, sodalite $\left(\mathrm{Na}_{8} \mathrm{Al}_{6} \mathrm{Si}_{6} \mathrm{O}_{24} \mathrm{Cl}_{2}\right)$, nosean $\left(\mathrm{Na}_{8} \mathrm{Al}_{6} \mathrm{Si}_{6} \mathrm{O}_{24} \mathrm{SO}_{4}\right)$ which were the main phases found in the 2004 SBW and LAW campaigns. The XRD spectra of the composite used in this study also indicated that some partially reacted $\mathrm{NaAl}_{5.9} \mathrm{O}_{9.4}$ and $\mathrm{SiO}_{2}$ from the misbatched SBW 2003 campaigns was present.

The oxide averages from Reference 2 were from final FBSR bed products that did not contain excess startup bed while many of the samples made to use the composite for monolith testing did contain excess startup bed. Therefore, an algorithm was written and regressed with a non-linear modeling routine in JMP software for all of the elements given in Table 4 except those that were 
missing values (either not measured or below detection limit) for any of the component streams. The algorithm fit the following equation to the final bed composite composition analyzed in this study (Table 4):

$$
\mathrm{a}_{1} \bullet \mathrm{Al}_{2} \mathrm{O}_{3}+\mathrm{a}_{2} \bullet \text { SBW03 }+\mathrm{a}_{3} \bullet \text { SBW04 }+\mathrm{a}_{4} \bullet \text { LAW04 }
$$

The non-linear fit indicated that $\mathrm{a}_{1}=44.5 \%, \mathrm{a}_{2}=17 \%, \mathrm{a}_{3}=14.9 \%$, and $\mathrm{a}_{4}=19.9 \%$ of the composite product. The resulting composition from this combination is shown in Table 4 for reference. The fit gives an adjusted $\mathrm{R}^{2}$ of $99.8 \%$ and a root mean square error (RMSE) of 0.7496. The contribution of the LAW04 material to the composite may be underestimated in the algorithm fit since $\mathrm{SO}_{3}$ is very high in the as measured composite, e.g. the LAW products (bed and fines) are the largest contributors to the $\mathrm{SO}_{3}$ content. This may be due to the fact that the $\mathrm{SO}_{3}$ in the nosean phase was not evenly distributed in the 2004 sample products either before or after the composite was mixed. 
Table 4. Oxide and Anion (Sodium Salt) Analyses of Steam Reformer Composite (Bed Products and Fines) Monolithed

\begin{tabular}{|c|c|c|c|c|c|}
\hline $\begin{array}{c}\text { Species } \\
(w t \%)\end{array}$ & $\begin{array}{l}2003 \text { SBW FBSR } \\
\text { Products (Average } \\
\text { of Bed } 260,272, \\
277 \text { ) from Ref. } 2\end{array}$ & $\begin{array}{l}2004 \text { SBW FBSR } \\
\text { Products (Bed } \\
\text { 1173) from Ref. } 2\end{array}$ & $\begin{array}{c}2004 \text { LAW } \\
\text { Envelope A } \\
\text { FBSR Products } \\
\text { (Average of Bed } \\
\text { 1103+1104+ Fines } \\
\text { 1125) from Ref. } 2\end{array}$ & $\begin{array}{c}\text { Analyzed } \\
\text { Composite of } 2004 \\
\text { LAW, 2004 SBW, } \\
2003 \mathrm{SBW} \\
\text { (analyzed in } \\
\text { quadruplicate for } \\
\text { this study) }\end{array}$ & $\begin{array}{l}\text { Algorithm Fit of } \\
\text { Composition in } \\
\text { terms of Startup } \\
\text { Bed, } 2004 \text { LAW, } \\
2004 \mathrm{SBW} \text {, and } \\
2003 \mathrm{SBW}\end{array}$ \\
\hline $\mathrm{Al}_{2} \mathrm{O}_{3}$ (ICP-ES) & 39.03 & 38.36 & 33.32 & 63.35 & 63.350 \\
\hline $\mathrm{CaO}$ (ICP-ES) & 0.75 & 3.79 & 1.96 & 1.46 & 1.065 \\
\hline $\mathrm{Cr}_{2} \mathrm{O}_{3}$ (ICP-ES) & NM & 0.10 & 0.12 & 0.04 & . \\
\hline $\mathrm{Cs}_{2} \mathrm{O}(\mathrm{ICP}-\mathrm{MS})$ & $7.12 \times 10^{-2}$ & $3.25 \times 10^{-2}$ & $1.51 \times 10^{-4}$ & $2.26 \times 10^{-2}$ & $1.67 \times 10^{-2}$ \\
\hline $\mathrm{Cu}_{2} \mathrm{O}$ (ICP-ES) & NM & 0.01 & 0.01 & $<0.01$ & . \\
\hline $\mathrm{Fe}_{2} \mathrm{O}_{3}$ (ICP-ES) & 1.74 & 1.012 & 0.333 & 1.389 & 0.506 \\
\hline $\mathrm{K}_{2} \mathrm{O}$ (ICP-ES) & 3.31 & 3.96 & 0.31 & 1.283 & 1.188 \\
\hline $\mathrm{La}_{2} \mathrm{O}_{3}$ (ICP-MS) & $6.68 \times 10^{-3}$ & $6.68 \times 10^{-3}$ & $6.68 \times 10^{-3}$ & $\mathrm{NM}$ & \\
\hline $\mathrm{MgO}$ (ICP-ES) & 0.205 & 0.40 & 0.06 & 0.14 & 0.104 \\
\hline $\mathrm{MnO}$ (ICP-ES) & NM & 0.36 & 0.04 & 0.10 & \\
\hline $\mathrm{Na}_{2} \mathrm{O}$ (ICP-ES) & 16.52 & 16.50 & 20.87 & 9.39 & 9.383 \\
\hline $\mathrm{NiO}$ (ICP-ES) & NM & 0.051 & 0.013 & 0.02 & \\
\hline $\mathrm{P}_{2} \mathrm{O}_{5}$ (ICP-ES) & 2.12 & 0.859 & 0.47 & 0.344 & 0.576 \\
\hline PbO (ICP-ES) & NM & $<0.1$ & $<0.1$ & 0.017 & \\
\hline $\mathrm{ReO}_{2}$ (ICP-MS) & $2.27 \times 10^{-2}$ & $5.57 \times 10^{-3}$ & $5.34 \times 10^{-3}$ & $3.00 \times 10^{-3}$ & $5.72 \times 10^{-3}$ \\
\hline $\mathrm{SiO}_{2}(\mathrm{ICP}-\mathrm{ES})$ & 35.63 & 37.65 & 38.12 & 19.056 & 19.132 \\
\hline $\mathrm{TiO}_{2}(\mathrm{ICP}-\mathrm{ES})$ & 1.14 & 1.19 & 1.23 & 0.537 & 0.612 \\
\hline $\mathrm{NaCl}(\mathrm{IC})$ & $<0.2$ & 0.152 & 0.225 & $\mathrm{BDL}$ & \\
\hline $\mathrm{NaF}(\mathrm{IC})$ & $<0.2$ & $<0.2$ & $<0.2$ & BDL & \\
\hline $\mathrm{NaI}(\mathrm{IC})$ & $\mathrm{NM}$ & $\mathrm{NM}$ & $<2 \times 10^{-5}$ & NM & \\
\hline $\mathrm{SO}_{3}$ (ICP-ES) & 0.419 & 0.103 & 0.766 & 2.65 & 0.241 \\
\hline SUM & 100.86 & 104.50 & 97.85 & 99.78 & 96.34 \\
\hline
\end{tabular}




\subsection{Monolith Density and Compressive Strength}

Four of the five cement monoliths fabricated and tested in this study had compressive strengths $>500$ psi after 7 days (Table 5; Figure 8). Because cement reaches $75 \%$ of its full compressive strength in 7 days and the 500 psi criteria is a 28 day criteria, these four (A,B,C,D) cement formulations will have adequate compressive strength for making monoliths. Table 5 and Figure 8 indicate that a $5 \%$ substitution of precipitated $\mathrm{SiO}_{2}$ for OPC as a pozzolanic additive improved the cement monolith compressive strength up to 2710 psi (formulation D) while a $17.5 \%$ substitution of precipitated $\mathrm{SiO}_{2}$ for OPC decreased the compressive strength (formulation $\mathrm{E}$ ) at equivalent ( $\sim 80 \%$ ) FBSR loading. Dropping the waste loading to $80 \mathrm{wt} \%$ (formulation C) from $84 \mathrm{wt} \%$ (formulation A) and $87 \mathrm{wt} \%$ (formulation B) improved the compressive strength (Table 5; Figure 8).

The Ceramicrete monolith density and compressive strengths were measured at SRNL and ANL (Table 5). While the density measurements of the two laboratories agree, the SRNL compressive strength measurements were higher than those of ANL. It should be noted that the Ceramicrete monoliths were fabricated in December 2005 and tested by ANL after 14 days and tested by SRNL on February 9, 2006 after an additional $\sim 1$ month of setting time. This may explain the increased compressive strength determined by SRNL. ANL's compressive strength value was used for comparative purposes and is plotted in Figure 8.

None of the hydroceramics cured at $40^{\circ} \mathrm{C}$ for 24 hours had adequate ( $\geq 500$ psi) compressive strengths (Table 5). None of the hydroceramics cured at $70^{\circ} \mathrm{C}$ for 1 week had adequate $(\geq 500$ psi) compressive strengths although formulation $\mathrm{C}$ with the highest waste loading was $\sim 500 \mathrm{psi}$ (490 psi) and would probably exceed this compressive strength in a 28 day cure (Table 5). The increase in density and the increase in compressive strength with waste loading indicate that the FBSR product may be taking part in the curing reaction with the additional metakaolin and $\mathrm{NaOH}$. The densest and highest waste loaded hydroceramic cured at $90^{\circ} \mathrm{C}$ for 1 week had superior compressive strength (>1500 psi) compared to all the other hydroceramics fabricated at $90^{\circ} \mathrm{C}$. The $90^{\circ} \mathrm{C}$ cured sample compressive strengths are plotted in Figure 8 . While this figure shows which of the materials tested met the stated waste loading criteria for Envelope A waste, it does not determine which are capable of meeting that criteria.

All of the monoliths except one cement and one hydroceramic had $>500$ psi strength after either 7 (cement and hydroceramics) or 14 (Ceramicrete) day cures. Of the samples tested with 60-87 $\mathrm{wt} \%$ FBSR product (Figure 8 ) only one sample did not achieve the $>500$ psi strength requirement (Cement $\mathrm{E})$. 
Table 5. SRNL Monolith Density (g/cc) and Compressive Strength (psi)

\begin{tabular}{|c|c|c|c|}
\hline $\begin{array}{c}\text { Monolith } \\
\text { Identification } \\
\end{array}$ & $\begin{array}{c}\text { Density } \\
\text { (g/cc) }\end{array}$ & $\begin{array}{l}\text { Compressive } \\
\text { Strength (psi) }\end{array}$ & $\begin{array}{l}\text { Waste Loading } \\
\text { (\% dry basis) }\end{array}$ \\
\hline \multicolumn{4}{|c|}{ CEMENT MONOLITHS } \\
\hline $\mathrm{A}$ & 1.68 & 890 & 84 \\
\hline $\mathrm{B}$ & 1.61 & 810 & 87 \\
\hline $\mathrm{C}$ & 1.72 & 1180 & 80 \\
\hline $\mathrm{D}$ & 1.38 & 2710 & 80 \\
\hline $\mathrm{E}$ & 1.18 & 250 & 81 \\
\hline \multicolumn{4}{|c|}{ CERAMICRETE MONOLITHS } \\
\hline SRNL & 2.15 (3 replicates) & 7100 & 35.7 \\
\hline ANL & 2.14 & 4161 & 35.7 \\
\hline \multicolumn{4}{|c|}{ HYDROCERAMICS CURED AT $40^{\circ} \mathrm{C}$} \\
\hline $\mathrm{A}$ & 1.56 & 76 & 50 \\
\hline $\mathrm{B}$ & 1.66 & 80 & 60 \\
\hline $\mathrm{C}$ & 1.80 & 106 & 80 \\
\hline \multicolumn{4}{|c|}{ HYDROCERAMICS CURED AT $70^{\circ} \mathrm{C}$} \\
\hline A-2 & 1.48 & 272 & 50 \\
\hline B-2 & 1.53 & 320 & 60 \\
\hline $\mathrm{C}-2$ & 1.59 & 479 & 80 \\
\hline \multicolumn{4}{|c|}{ HYDROCERAMICS CURED AT $90^{\circ} \mathrm{C}$} \\
\hline A-3-a & 1.50 & 80 & 50 \\
\hline A-3-b & 1.38 & 250 & 50 \\
\hline $\mathrm{B}-3-\mathrm{a}$ & 1.50 & 710 & 60 \\
\hline B-3-b & 1.50 & 290 & 60 \\
\hline C-3-a & 1.61 & 1540 & 83.3 \\
\hline $\mathrm{C}-3-\mathrm{b}$ & 1.78 & 820 & 83.3 \\
\hline
\end{tabular}



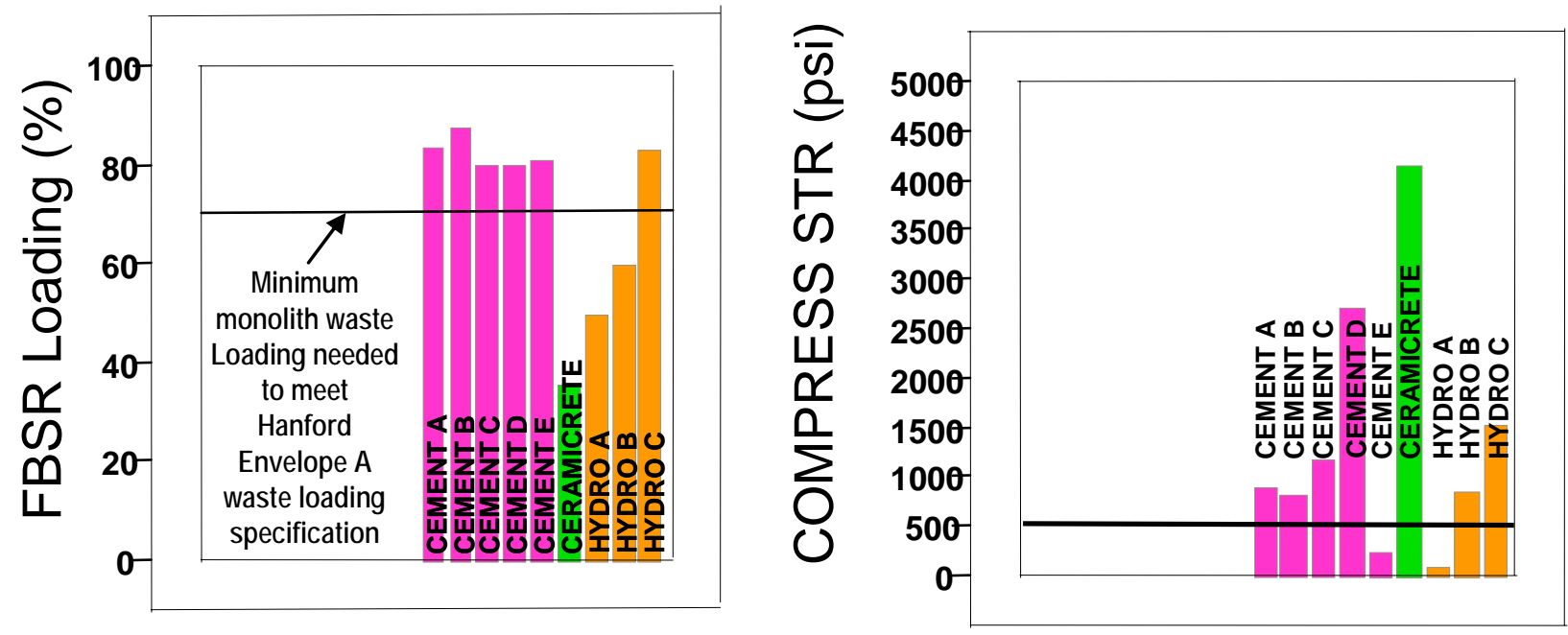

Figure 8. Comparative FBSR loadings (dry wt $\%$ basis) in monolith and compressive strengths. All but two of the monoliths had $>500$ psi compressive strength. Five of the nine monoliths tested were $>500$ psi and contained $\geq 60 \mathrm{wt} \%$ FBSR product.

\subsection{Monolith Characterization and Waste Loading}

Durability testing via the Product Consistency Test requires that the fraction of each element in the monolithic solid be known (see $f_{i}$ term in Equations 1 and 2). Therefore, the $w t \%$ of each element in the monoliths was analyzed (Table 8) including the amount of water. A mass balance was performed on the analyses. The samples were then converted to an anhydrous basis to determine the $f_{i}$ on a dry weight basis as the water content of the monoliths does not participate in the leaching (Table 9).

In addition, the Hanford contract specification (Section 2.2.2.2) requires that the $\mathrm{Na}_{2} \mathrm{O}$ loading of the waste form in terms of $\mathrm{Na}_{2} \mathrm{O}$ content (wt\%) of the Envelope A wastes be $14 \mathrm{wt} \%$. The starting FBSR product used in this study contained $20.87 \mathrm{wt} \% \mathrm{Na}_{2} \mathrm{O}$ from Envelope A waste (Table 4). In this product all of the $\mathrm{Na}_{2} \mathrm{O}$ came from the Envelope A waste as only kaolin was added. If the FBSR product monoliths in this study were all Envelope A waste instead of a mixture of Envelope A waste form, SBW waste form, and startup bed $\mathrm{Al}_{2} \mathrm{O}_{3}$, then multiplication of the $20.87 \mathrm{wt} \% \mathrm{Na}_{2} \mathrm{O}$ in the LAW Envelope A FBSR waste form by the FBSR waste loadings achieved in this study (Table 5 and Figure 8) gives an indication of the $\mathrm{Na}_{2} \mathrm{O}$ loadings that could be achieved. This comparison indicates that monolith waste forms for Hanford Envelope A waste must have FBSR waste loadings $>67 \mathrm{wt} \%$ in order to meet the Hanford waste loading specification. This is indicated in Table 6 and Figure 8. It should be noted that the Hanford Envelope A waste loading specification is more stringent than the remaining Envelope waste loadings which are $3 \mathrm{wt} \% \mathrm{Na}_{2} \mathrm{O}$ for Envelope $\mathrm{B}$ wastes and $10 \mathrm{wt} \% \mathrm{Na}_{2} \mathrm{O}$ for Envelope $\mathrm{C}$ wastes. It should also be noted that testing has indicated which of the materials tested met the stated waste loading criteria, the limited testing performed does not indicate which binders are 
capable of meeting that criteria. In particular, the Ceramicrete binder will require additional testing at higher waste loadings to verify that the compressive strength and other properties are acceptable at $\geq 67 \mathrm{wt} \%$ FBSR loading.

Table 6. Theoretically Calculated LAW Envelope A Waste Loadings Based on $\mathrm{Na}_{2} \mathrm{O}(\mathrm{wt} \%)$

\begin{tabular}{|c|c|c|c|}
\hline $\begin{array}{c}\text { Monolith } \\
\text { Identification }\end{array}$ & $\begin{array}{c}\text { Waste Loading } \\
\text { (WL) } \\
\text { (\% dry basis) }\end{array}$ & $\begin{array}{c}\text { Na } \mathbf{O} \text { (wt\%) } \\
\text { (WL * 20.87 Na } \mathbf{O} \\
\text { from Table 4) }\end{array}$ & $\begin{array}{c}\text { >14 wt\% Na } \mathbf{O} \text { in } \\
\text { Waste }\end{array}$ \\
\hline CEMENT MONOLITHS & 17.53 & YES \\
\hline A & 84 & 18.16 & YES \\
\hline B & 87 & 16.70 & YES \\
\hline C & 80 & 16.70 & YES \\
\hline D & 80 & 16.90 & NO \\
\hline E & 81 & 7.45 & NO \\
\hline CERAMICRETE MONOLITHS & 35.7 & 10.44 & NO \\
\hline ANL & 50 & $16.70 / 17.39$ & YES \\
\hline HYDROCERAMICS & 60 &
\end{tabular}

The phases found in cement monolith $\mathrm{D}$ after a 7 day cure are given in Table 7 . The major phases are calcite formed from excess $\mathrm{CaOH}$ in the cement as it hydrates and reaction with $\mathrm{CO}_{2}$ in the air and the nepheline $\left(\mathrm{NaAlSiO}_{4}\right)$ product in the original composite FBSR product. Some minor $\mathrm{AlPO}_{4}$ was also found, likely a component of the OPC. The sodalite and nosean phases were not observed in the X-ray diffraction spectra. This may be because these are minor phases in the FBSR composite product that was monolithed. Some $\mathrm{SiO}_{2}$ was also observed which could be from the precipitated $\mathrm{SiO}_{2}$ added to react with excess $\mathrm{CaOH}$ as the cement set. The $\mathrm{Al}_{2} \mathrm{O}_{3}$ found in the bed product was not observed.

The XRD of the Ceramicrete indicated the presence of the $\mathrm{Al}_{2} \mathrm{O}_{3}$ bed material in the FBSR product that was monolithed and $\mathrm{SiO}_{2}$ (Table 7). The main FBSR mineral nepheline $\left(\mathrm{NaAlSiO}_{4}\right)$ was present but the sodalite and nosean phases were not observed in the X-ray diffraction spectra. This may be because these are minor phases in the FBSR product and the FBSR product loading was only $37.5 \%$. The $\mathrm{KMgPO}_{4} \bullet \mathrm{H}_{2} \mathrm{O}$ phase that is the Ceramicrete binder was also present as a major phase in the spectra.

Hydroceramic $\mathrm{C}$ (set at $40^{\circ} \mathrm{C}$ ) was analyzed by XRD and the phases found are indicated in Table 7. Two different types of nepheline were found one of the normal hexagonal crystal symmetry as found in the Hazen Hanford Envelope C FBSR products and the INL SBW products. The other nepheline present was of the same stoichiometry but of orthorhombic symmetry. In addition, a cubic phase of $\mathrm{Na}_{96} \mathrm{Al}_{96} \mathrm{Si}_{96} \mathrm{O}_{384}$ was identified which is anhydrous Zeolite-A. Zeolite $\mathrm{A}$ has the same structure as nosean and sodalite identified in the raw FBSR composite used in 
this study and is likely these phases and not anhydrous Zeolite-A which would not form at the $40^{\circ} \mathrm{C}$ used to set these hydroceramics.

Table 7. X-ray Diffraction Analysis of Phases in the FBSR Composite Before and After Monolithing

\begin{tabular}{|c|c|c|c|c|}
\hline PHASES & $\begin{array}{c}\text { FBSR } \\
\text { COMPOSITE } \\
\text { USED IN } \\
\text { THIS STUDY } \\
\end{array}$ & CEMENT & CERAMICRETE & HYDROCERAMIC \\
\hline $\begin{array}{c}\mathrm{Al}_{2} \mathrm{O}_{3} \\
\text { (startup bed) }\end{array}$ & MAJOR & --- & MAJOR & --- \\
\hline $\begin{array}{c}\text { Nepheline } \\
\mathrm{Na}_{6.8} \mathrm{Al}_{6.3} \mathrm{Si}_{9.7} \mathrm{O}_{32} \\
\text { or } \mathrm{NaAlSiO}_{4}\end{array}$ & MAJOR & MAJOR & MAJOR & MAJOR \\
\hline $\begin{array}{c}\text { Sodalite } \\
\mathrm{Na}_{8} \mathrm{Al}_{6} \mathrm{Si}_{6} \mathrm{O}_{24} \mathrm{Cl}_{2}\end{array}$ & MINOR & --- & --- & --- \\
\hline $\begin{array}{c}\text { Nosean } \\
\mathrm{Na}_{8} \mathrm{Al}_{6} \mathrm{Si}_{6} \mathrm{O}_{24} \mathrm{SO}_{4}\end{array}$ & MINOR & --- & --- & --- \\
\hline $\begin{array}{c}\text { Anhydrous } \\
\text { Zeolite A }\end{array}$ & --- & --- & --- & MAJOR \\
\hline $\begin{array}{c}\text { Unreacted } \\
\mathrm{NaAl}_{5.9} \mathrm{O}_{9.4} \text { from } \\
\text { INL } 2003 \text { tests } \\
\end{array}$ & MINOR & --- & --- & --- \\
\hline $\mathrm{SiO}_{2}$ & MINOR & MINOR & --- & MINOR \\
\hline Calcite $\mathrm{CaCO}_{3}$ & --- & MINOR & --- & --- \\
\hline $\mathrm{AlPO}_{4}$ & --- & MINOR & --- & --- \\
\hline $\mathrm{KMgPO}_{4} \bullet \mathrm{H}_{2} \mathrm{O}$ & --- & --- & MAJOR & --- \\
\hline
\end{tabular}

\subsection{Monolith Durability Testing}

The surface area of all of the samples was measured by the BET method given in Section 4.7 using $\mathrm{N}_{2}$ and measured geometrically. The comparison is given in Table 10. The surface roughness factors given in Table 10 are the BET surface area divided by the geometric surface area.

From Table 10 it can be seen that the cement and Ceramicrete monoliths have much higher BET surface areas than the hydroceramics. This is likely due to the fact that when cement hydrates needle like crystallites of calcium silicate hydrate (CSH) form that are initially hydrous and crystallize giving an interlocking structure that gives concrete its strength. These CSH phases create additional surface area. A similar mechanism is likely during the hydration of Ceramicrete into the hydrated $\mathrm{MgKPO}_{4} \bullet 6 \mathrm{H}_{2} \mathrm{O}$ phase observed in the XRD analysis. A comparison of the BET surface areas of the bed products in the pre-monolithed samples and the monolithed samples is given in Figure 9. 
Table 8. Chemically Analyzed Composition (wt\%) of Monoliths on Hydrous Basis

\begin{tabular}{|c|c|c|c|c|c|c|c|c|c|}
\hline $\begin{array}{c}\text { Species } \\
\text { (wt\%) }\end{array}$ & $\begin{array}{c}\text { Cement } \\
\text { A }\end{array}$ & $\begin{array}{c}\text { Cement } \\
\text { B }\end{array}$ & $\begin{array}{c}\text { Cement } \\
\text { C }\end{array}$ & $\begin{array}{c}\text { Cement } \\
\text { D }\end{array}$ & $\begin{array}{c}\text { Cement } \\
\text { E }\end{array}$ & $\begin{array}{l}\text { Cerami- } \\
\text { crete }\end{array}$ & $\begin{array}{c}\text { Hydro- } \\
\text { ceramic } \\
\text { A-2 }\end{array}$ & $\begin{array}{l}\text { Hydro- } \\
\text { ceramic } \\
\text { B-2 }\end{array}$ & $\begin{array}{c}\text { Hydro- } \\
\text { ceramic } \\
\text { C-2 }\end{array}$ \\
\hline $\mathrm{Al}_{2} \mathrm{O}_{3}$ (ICP-ES) & 19.159 & 18.885 & 17.501 & 15.160 & 15.388 & 13.428 & 31.154 & 29.005 & 29.618 \\
\hline $\mathrm{CaO}$ (ICP-ES) & 16.787 & 14.209 & 17.138 & 17.072 & 14.568 & 8.451 & 1.048 & 1.217 & 1.932 \\
\hline CdO (ICP-ES) & 0.022 & 0.022 & 0.022 & 0.022 & 0.022 & 0.021 & 0.021 & 0.021 & 0.021 \\
\hline $\mathrm{Cr}_{2} \mathrm{O}_{3}(\mathrm{ICP}-\mathrm{ES})$ & 0.052 & 0.053 & 0.049 & 0.044 & 0.044 & 0.046 & 0.025 & 0.028 & 0.047 \\
\hline $\mathrm{Cs}_{2} \mathrm{O}$ (ICP-MS) & 0.030 & 0.034 & 0.026 & 0.022 & 0.028 & 0.009 & 0.014 & 0.018 & 0.031 \\
\hline $\mathrm{CuO}$ (ICP-ES) & 0.071 & 0.031 & 0.029 & 0.025 & 0.022 & 0.020 & 0.014 & 0.014 & 0.014 \\
\hline $\mathrm{Fe}_{2} \mathrm{O}_{3}(\mathrm{ICP}-\mathrm{ES})$ & 1.699 & 1.589 & 1.684 & 1.642 & 1.543 & 2.400 & 1.362 & 1.270 & 1.336 \\
\hline $\mathrm{K}_{2} \mathrm{O}$ (ICP-ES) & 1.571 & 1.683 & 1.454 & 1.273 & 1.304 & 12.855 & 1.086 & 1.151 & 1.603 \\
\hline $\mathrm{La}_{2} \mathrm{O}_{3}(\mathrm{ICP}-\mathrm{MS})$ & 0.022 & 0.022 & 0.022 & 0.022 & 0.022 & 0.021 & 0.021 & 0.021 & 0.021 \\
\hline $\mathrm{MgO}$ (ICP-ES) & 0.492 & 0.467 & 0.487 & 0.486 & 0.455 & 9.216 & 0.271 & 0.262 & 0.330 \\
\hline $\mathrm{MnO}$ (ICP-ES) & 0.135 & 0.145 & 0.127 & 0.116 & 0.124 & 0.055 & 0.051 & 0.064 & 0.125 \\
\hline $\mathrm{Na}_{2} \mathrm{O}$ (ICP-ES) & 11.038 & 11.928 & 10.535 & 9.804 & 8.875 & 4.041 & 10.336 & 11.298 & 15.940 \\
\hline $\mathrm{NiO}$ (ICP-ES) & 0.027 & 0.026 & 0.025 & 0.021 & 0.022 & 0.021 & 0.014 & 0.015 & 0.024 \\
\hline $\mathrm{P}_{2} \mathrm{O}_{5}$ (ICP-ES) & 0.408 & 0.445 & 0.382 & 0.367 & 0.398 & 15.238 & 0.199 & 0.234 & 0.464 \\
\hline $\mathrm{PbO}$ (ICP-ES) & 0.033 & 0.036 & 0.032 & 0.031 & 0.031 & 0.024 & 0.024 & 0.024 & 0.030 \\
\hline $\mathrm{ReO}_{2}$ (ICP-MS) & $3.41 \mathrm{E}-03$ & $3.36 \mathrm{E}-03$ & $3.42 \mathrm{E}-03$ & $3.49 \mathrm{E}-03$ & $3.40 \mathrm{E}-03$ & $3.29 \mathrm{E}-03$ & $3.71 \mathrm{E}-03$ & $4.14 \mathrm{E}-03$ & $5.21 \mathrm{E}-03$ \\
\hline $\mathrm{SO}_{3}(\mathrm{ICP}-\mathrm{ES})$ & 3.465 & 4.310 & 3.383 & 3.958 & 3.103 & 1.664 & 1.191 & 1.382 & 1.677 \\
\hline $\mathrm{SiO}_{2}$ (ICP-ES) & 26.289 & 25.976 & 24.319 & 23.302 & 25.687 & 18.061 & 43.849 & 40.271 & 37.887 \\
\hline $\mathrm{TiO}_{2}$ (ICP-ES) & 0.849 & 0.871 & 0.788 & 0.724 & 0.759 & 0.695 & 1.186 & 1.135 & 1.121 \\
\hline $\mathrm{Cl}(\mathrm{IC})$ & $<0.100$ & $<0.100$ & $<0.100$ & $<0.100$ & $<0.100$ & $<0.100$ & $<0.100$ & $<0.100$ & $<0.100$ \\
\hline $\mathrm{F}(\mathrm{IC})$ & $<0.100$ & $<0.100$ & $<0.100$ & $<0.100$ & $<0.100$ & $<0.100$ & $<0.100$ & $<0.100$ & $<0.100$ \\
\hline $\mathrm{NO}_{3} / \mathrm{NO}_{2}(\mathrm{IC})$ & $<0.100$ & $<0.100$ & $<0.100$ & $<0.100$ & $<0.100$ & $<0.100$ & $<0.100$ & $<0.100$ & $<0.100$ \\
\hline $\mathrm{H}_{2} \mathrm{O}$ (wt loss) & 16.480 & 14.550 & 16.650 & 19.040 & 16.010 & 12.270 & 12.930 & 12.050 & 10.000 \\
\hline SUM & 98.633 & 95.283 & 94.657 & 93.137 & 88.407 & 98.541 & 104.801 & 99.486 & 102.227 \\
\hline
\end{tabular}


Table 9. Chemically Analyzed Composition (wt\%) of Monoliths on Anhydrous Basis

\begin{tabular}{|c|c|c|c|c|c|c|c|c|c|}
\hline $\begin{array}{c}\text { Species } \\
(\mathbf{w t} \%)\end{array}$ & $\begin{array}{c}\text { Cement } \\
\text { A }\end{array}$ & $\begin{array}{c}\text { Cement } \\
\text { B }\end{array}$ & $\begin{array}{c}\text { Cement } \\
\text { C }\end{array}$ & $\begin{array}{c}\text { Cement } \\
\text { D }\end{array}$ & $\begin{array}{c}\text { Cement } \\
\text { E }\end{array}$ & $\begin{array}{l}\text { Cerami- } \\
\text { crete }\end{array}$ & $\begin{array}{c}\text { Hydro- } \\
\text { ceramic } \\
\text { A-2 }\end{array}$ & $\begin{array}{c}\text { Hydro- } \\
\text { ceramic } \\
\text { B-2 }\end{array}$ & $\begin{array}{c}\text { Hydro- } \\
\text { ceramic } \\
\text { C-2 }\end{array}$ \\
\hline $\mathrm{Al}_{2} \mathrm{O}_{3}(\mathrm{ICP}-\mathrm{ES})$ & 23.321 & 23.391 & 22.435 & 20.460 & 21.255 & 15.565 & 33.910 & 33.173 & 32.114 \\
\hline $\mathrm{CaO}$ (ICP-ES) & 20.434 & 17.600 & 21.970 & 23.041 & 20.123 & 9.796 & 1.140 & 1.392 & 2.094 \\
\hline CdO (ICP-ES) & 0.027 & 0.027 & 0.028 & 0.030 & 0.030 & 0.025 & 0.023 & 0.024 & 0.023 \\
\hline $\mathrm{Cr}_{2} \mathrm{O}_{3}$ (ICP-ES) & 0.063 & 0.065 & 0.062 & 0.060 & 0.061 & 0.053 & 0.027 & 0.032 & 0.051 \\
\hline $\mathrm{Cs}_{2} \mathrm{O}$ (ICP-MS) & 0.036 & 0.042 & 0.033 & 0.030 & 0.038 & 0.011 & 0.015 & 0.021 & 0.034 \\
\hline $\mathrm{CuO}$ (ICP-ES) & 0.087 & 0.038 & 0.037 & 0.034 & 0.030 & 0.024 & 0.015 & 0.016 & 0.016 \\
\hline $\mathrm{Fe}_{2} \mathrm{O}_{3}(\mathrm{ICP}-\mathrm{ES})$ & 2.068 & 1.968 & 2.159 & 2.216 & 2.132 & 2.782 & 1.482 & 1.453 & 1.449 \\
\hline $\mathrm{K}_{2} \mathrm{O}$ (ICP-ES) & 1.913 & 2.085 & 1.864 & 1.718 & 1.801 & 14.900 & 1.182 & 1.317 & 1.738 \\
\hline $\mathrm{La}_{2} \mathrm{O}_{3}$ (ICP-MS) & 0.027 & 0.027 & 0.028 & 0.030 & 0.030 & 0.025 & 0.023 & 0.024 & 0.023 \\
\hline $\mathrm{MgO}$ (ICP-ES) & 0.598 & 0.579 & 0.625 & 0.655 & 0.628 & 10.682 & 0.295 & 0.300 & 0.358 \\
\hline $\mathrm{MnO}$ (ICP-ES) & 0.165 & 0.180 & 0.163 & 0.157 & 0.172 & 0.064 & 0.056 & 0.073 & 0.136 \\
\hline $\mathrm{Na}_{2} \mathrm{O}$ (ICP-ES) & 13.436 & 14.775 & 13.506 & 13.232 & 12.258 & 4.684 & 11.251 & 12.921 & 17.284 \\
\hline $\mathrm{NiO}$ (ICP-ES) & 0.033 & 0.032 & 0.032 & 0.029 & 0.031 & 0.024 & 0.016 & 0.017 & 0.026 \\
\hline $\mathrm{P}_{2} \mathrm{O}_{5}$ (ICP-ES) & 0.496 & 0.551 & 0.489 & 0.495 & 0.549 & 17.664 & 0.217 & 0.267 & 0.503 \\
\hline $\mathrm{PbO}$ (ICP-ES) & 0.040 & 0.044 & 0.041 & 0.042 & 0.042 & 0.028 & 0.026 & 0.028 & 0.032 \\
\hline $\mathrm{ReO}_{2}$ (ICP-MS) & 0.004 & 0.004 & 0.004 & 0.005 & 0.005 & 0.004 & 0.004 & 0.005 & 0.006 \\
\hline $\mathrm{SO}_{3}(\mathrm{ICP}-\mathrm{ES})$ & 4.218 & 5.338 & 4.336 & 5.342 & 4.286 & 1.929 & 1.297 & 1.581 & 1.819 \\
\hline $\mathrm{SiO}_{2}(\mathrm{ICP}-\mathrm{ES})$ & 32.000 & 32.175 & 31.175 & 31.447 & 35.480 & 20.936 & 47.729 & 46.058 & 41.080 \\
\hline $\mathrm{TiO}_{2}$ (ICP-ES) & 1.033 & 1.079 & 1.010 & 0.977 & 1.048 & 0.805 & 1.291 & 1.299 & 1.216 \\
\hline SUM & 100.000 & 100.000 & 100.000 & 100.000 & 100.000 & 100.000 & 100.000 & 100.000 & 100.000 \\
\hline
\end{tabular}


Table 10. Measured BET Surface Area and Geometric Surface Area in $\mathrm{m}^{2} / \mathrm{g}$

\begin{tabular}{|c|c|c|c|}
\hline Monolith & $\begin{array}{c}\text { BET Surface } \\
\text { Area } \\
\left(\mathrm{m}^{2} / \mathrm{g}\right)\end{array}$ & $\begin{array}{c}\text { Geometric } \\
\text { Surface Area } \\
\left(\mathrm{m}^{2} / \mathrm{g}\right)^{*}\end{array}$ & $\begin{array}{c}\text { Surface } \\
\text { Roughness } \\
\text { Factor }\end{array}$ \\
\hline Cement A & 17.23 & 0.0319 & 540.13 \\
\hline Cement B & 17.06 & 0.0333 & 512.31 \\
\hline Cement C & 30.05 & 0.0311 & 966.24 \\
\hline Cement D & 41.76 & 0.0388 & 1076.29 \\
\hline Cement E & 20.54 & 0.0454 & 452.42 \\
\hline Ceramicrete & 21.66 & 0.0249 & 869.88 \\
\hline Hydroceramic A & 6.17 & 0.0362 & 170.44 \\
\hline Hydroceramic B & 5.85 & 0.0350 & 167.14 \\
\hline Hydroceramic C & 3.27 & 0.0337 & 97.033 \\
\hline
\end{tabular}

* calculated from densities given in Table 5 .

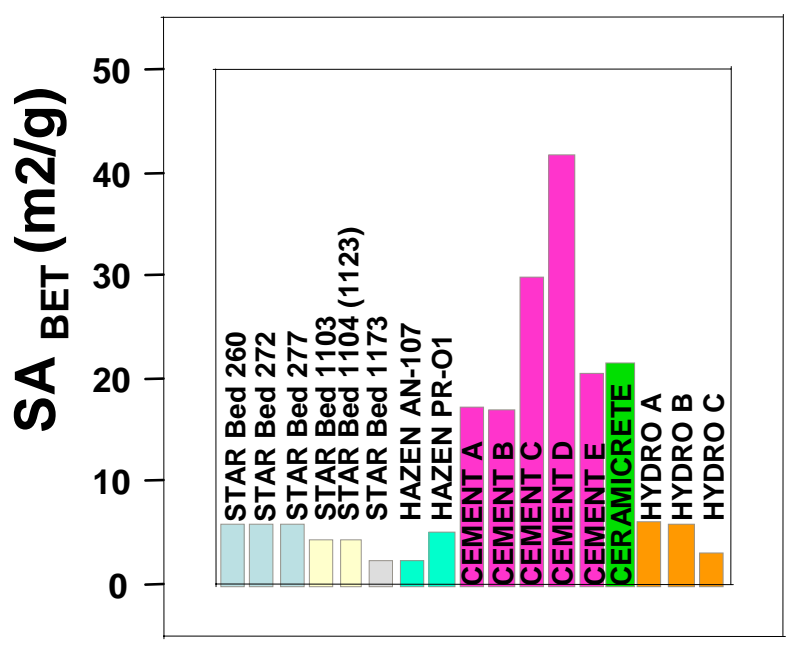

Figure 9. Comparative BET surface area $\left(\mathrm{m}^{2} / \mathrm{g}\right)$ of STAR and Hazen FBSR bed and fines products to the surface area of the STAR products embedded in concrete, Ceramicrete, and hydroceramics.

All of the monoliths were durability tested in triplicate per the PCT procedure. The conditions outlined in Section 4.7 were used. Glass standards were used to ensure test control as required by the PCT procedure and the standard releases (Table 11 and

Table 12) agreed with previous round robin testing of these glasses. ${ }^{10}$ Analyses of blank vessels indicated that the vessels were clean. Due to timing constraints the hydroceramics set at $40^{\circ} \mathrm{C}$ were leach tested while the curing conditions to increase strength were optimized.

Table 13 gives the triplicate leachate results in ppm measured after the 7 day PCT tests were completed. Table 14 gives the triplicate leachate results in $\mathrm{g} / \mathrm{m}^{2}$ after calculation using 
Equations 1 and 4. The BET surface areas used were those in Table 10 and the $f_{i}$ values were derived from the data in Table 9. The average triplicate leach responses are tabulated in Table 15 .

Table 11. PCT Leachate standards and blanks (ppm)

\begin{tabular}{|c|c|c|c|c|c|}
\hline $\begin{array}{c}\text { Species } \\
\text { (ppm) }\end{array}$ & Blank & $\begin{array}{c}\text { ARM-1 } \\
\text { Glass } \\
\text { This Study }\end{array}$ & $\begin{array}{c}\text { ARM-1 } \\
\text { Glass } \\
\text { Round } \\
\text { Robin }\end{array}$ & $\begin{array}{c}\text { EA } \\
\text { Glass } \\
\text { This Study }\end{array}$ & $\begin{array}{c}\text { EA } \\
\text { Glass } \\
\text { Round } \\
\text { Robin 10 }\end{array}$ \\
\hline $\mathrm{pH}-1$ & 6.9 & 9.93 & $10.17 \pm 0.29$ & 11.63 & $11.85 \pm 0.1$ \\
\hline $\mathrm{pH}-2$ & 6.84 & 9.96 & $10.17 \pm 0.29$ & 11.64 & $11.85 \pm 0.1$ \\
\hline $\mathrm{pH}-3$ & $\mathrm{NM}$ & 9.96 & $10.17 \pm 0.29$ & 11.66 & $11.85 \pm 0.1$ \\
\hline $\mathrm{Al}-1$ & $<0.100$ & 4.55 & $4.58 \pm 0.50$ & 1.54 & $\mathrm{NM}$ \\
\hline $\mathrm{Al}-2$ & $<0.100$ & 4.59 & $4.58 \pm 0.50$ & 1.56 & $\mathrm{NM}$ \\
\hline $\mathrm{Al}-3$ & $\mathrm{NM}$ & 4.54 & $4.58 \pm 0.50$ & 1.55 & $\mathrm{NM}$ \\
\hline $\mathrm{Na}-1$ & 0.749 & 36.34 & $36.22 \pm 2.45$ & 1561.67 & $1662 \pm 112$ \\
\hline $\mathrm{Na}-2$ & $<0.100$ & 32.61 & $36.22 \pm 2.45$ & 1556.67 & $1662 \pm 112$ \\
\hline $\mathrm{Na}-3$ & $\mathrm{NM}$ & 37.52 & $36.22 \pm 2.45$ & 1620.00 & $1662 \pm 112$ \\
\hline $\mathrm{Si}-1$ & $<0.200$ & 56.60 & $61.23 \pm 4.07$ & 841.49 & $893 \pm 86$ \\
\hline $\mathrm{Si}-2$ & $<0.200$ & 56.05 & $61.23 \pm 4.07$ & 840.60 & $893 \pm 86$ \\
\hline Si-3 & $\mathrm{NM}$ & 54.80 & $61.23 \pm 4.07$ & 838.81 & $893 \pm 86$ \\
\hline $\mathrm{Cs}-1$ & $<0.00001$ & 1.88 & $\mathrm{NM}$ & N/A & N/A \\
\hline Cs-2 & $<0.00001$ & 2.08 & $\mathrm{NM}$ & N/A & N/A \\
\hline Cs-3 & $\mathrm{NM}$ & 1.80 & $\mathrm{NM}$ & $\mathrm{N} / \mathrm{A}$ & N/A \\
\hline
\end{tabular}

$\mathrm{NM}=$ not measured

Table 12. PCT Leachate Standards (g/L)

\begin{tabular}{|c|c|c|c|c|}
\hline $\begin{array}{c}\text { Species } \\
\left(\mathbf{g} / \mathbf{m}^{\mathbf{2}}\right)\end{array}$ & $\begin{array}{c}\text { ARM-1 } \\
\text { Glass } \\
\text { This Study } \\
\mathbf{( g / L )}\end{array}$ & $\begin{array}{c}\text { ARM-1 } \\
\text { Glass } \\
\text { Round } \\
\text { Robin }^{39} \\
\mathbf{( g / L )}\end{array}$ & $\begin{array}{c}\text { EA } \\
\text { Glass } \\
\text { This Study } \\
\mathbf{( g / L )}\end{array}$ & $\begin{array}{c}\text { EA Glass } \\
\text { Round } \\
\text { Robin } \\
\mathbf{( g / L )}\end{array}$ \\
\hline Al-avg & 0.153 & $0.155 \pm 0.0172$ & 0.08 & NM \\
\hline Na-avg & 0.49 & $0.505 \pm 0.0539$ & 12.67 & $13.346 \pm 0.902$ \\
\hline Si-avg & 0.26 & $0.282 \pm 0.0300$ & 3.69 & $3.922 \pm 0.376$ \\
\hline
\end{tabular}

$\mathrm{NM}=$ not measured 
Table 13. PCT Leachate Concentrations (ppm)

\begin{tabular}{|c|c|c|c|c|c|c|c|}
\hline $\begin{array}{c}\text { Monolith } \\
\text { Tested }\end{array}$ & pH & $\begin{array}{c}\text { Al } \\
(\mathbf{p p m})\end{array}$ & $\begin{array}{c}\mathrm{Cs} \\
(\mathrm{ppm})\end{array}$ & $\begin{array}{c}\mathrm{Na} \\
(\mathbf{p p m})\end{array}$ & $\begin{array}{c}\operatorname{Re} \\
(\mathrm{ppm})\end{array}$ & $\begin{array}{c}\mathrm{S} \\
(\mathrm{ppm})\end{array}$ & $\begin{array}{c}\mathbf{S i} \\
(\mathbf{p p m})\end{array}$ \\
\hline Cement A-1 & 12.20 & 136.32 & 7.77 & 2616.67 & 2.72 & 7.88 & 37.37 \\
\hline Cement A-2 & 12.20 & 118.24 & 6.70 & 2366.67 & 2.50 & 7.96 & 43.63 \\
\hline Cement A-3 & 12.20 & 117.04 & 6.48 & 2516.67 & 2.47 & 8.23 & 44.21 \\
\hline Cement B-2 & 12.23 & 123.38 & 9.38 & 2983.33 & 2.22 & 15.30 & 27.06 \\
\hline Cement B-2 & 12.24 & 123.03 & 10.27 & 3083.33 & 2.43 & 15.50 & 25.13 \\
\hline Cement B-3 & 12.23 & 113.60 & 8.28 & 3066.67 & 2.30 & 18.15 & 27.44 \\
\hline Cement C-1 & 12.21 & 139.11 & 8.98 & 2933.33 & 2.67 & 10.89 & 38.14 \\
\hline Cement C-2 & 12.20 & 128.63 & 8.68 & 2716.67 & 2.22 & 10.80 & 43.82 \\
\hline Cement C-3 & 12.22 & 128.90 & 8.78 & 3166.67 & 2.27 & 10.96 & 43.24 \\
\hline Cement D-1 & 12.29 & 147.86 & 9.52 & 3050.00 & 3.42 & 10.96 & 26.86 \\
\hline Cement D-2 & 12.29 & 136.47 & 8.63 & 3150.00 & 3.42 & 10.96 & 29.22 \\
\hline Cement D-3 & 12.28 & 117.02 & 6.92 & 2716.67 & 3.18 & 10.96 & 35.70 \\
\hline Cement E-1 & 11.63 & 40.97 & 2.33 & 1348.00 & 1.38 & 10.96 & 33.28 \\
\hline Cement E-2 & 11.61 & 40.90 & 2.38 & 1402.56 & 1.80 & 10.96 & 33.07 \\
\hline Cement E-3 & 11.60 & 41.33 & 2.08 & 1199.66 & 1.92 & 10.96 & 33.16 \\
\hline Ceramicrete-1 & 10.12 & 4.54 & 1.72 & 645.99 & 1.43 & 10.96 & 16.63 \\
\hline Ceramicrete-2 & 10.11 & 4.41 & 1.72 & 643.53 & 1.19 & 10.96 & 16.25 \\
\hline Ceramicrete-3 & 10.10 & 4.29 & 1.68 & 645.49 & 1.29 & 10.96 & 16.22 \\
\hline Hydroceramic A-1 & 11.03 & 153.03 & 0.07 & 1004.96 & 0.60 & 10.96 & 31.44 \\
\hline Hydroceramic A-2 & 11.04 & 152.67 & 0.07 & 1059.38 & 0.66 & 10.96 & 30.39 \\
\hline Hydroceramic A-3 & 11.06 & 150.16 & 0.09 & 999.74 & 0.64 & 10.96 & 32.70 \\
\hline Hydroceramic B-1 & 11.29 & 104.62 & 0.12 & 930.70 & 0.34 & 10.96 & 46.34 \\
\hline Hydroceramic B-2 & 11.29 & 102.00 & 0.10 & 861.40 & 0.27 & 10.96 & 47.17 \\
\hline Hydroceramic B-3 & 11.30 & 104.59 & 0.10 & 924.35 & 0.34 & 10.96 & 47.61 \\
\hline Hydroceramic C-1 & 11.50 & 37.86 & 0.55 & 1079.69 & 0.61 & 10.96 & 86.14 \\
\hline Hydroceramic C-2 & 11.48 & 35.96 & 0.47 & 933.07 & 0.51 & 10.96 & 85.87 \\
\hline Hydroceramic C-3 & 11.45 & 34.38 & 0.38 & 801.89 & 0.44 & 10.96 & 83.81 \\
\hline
\end{tabular}


Table 14. PCT Leachate Concentrations $\left(\mathrm{g} / \mathrm{m}^{2}\right)$

\begin{tabular}{|c|c|c|c|c|c|c|}
\hline Monolith Tested & $\underset{\left(\mathrm{g} / \mathrm{m}^{2}\right)}{\mathrm{Al}}$ & $\underset{\left(\mathrm{g} / \mathrm{m}^{2}\right)}{\mathrm{Cs}}$ & $\underset{\left(\mathrm{g} / \mathrm{m}^{2}\right)}{\mathrm{Na}}$ & $\underset{\left(g / m^{2}\right)}{\operatorname{Re}}$ & $\underset{\left(g / m^{2}\right)}{S}$ & $\underset{\left(\mathbf{g} / \mathbf{m}^{2}\right)}{\mathbf{S i}}$ \\
\hline Cement A-1 & $6.41 \mathrm{E}-03$ & $1.32 \mathrm{E}-01$ & $1.52 \mathrm{E}-01$ & $4.45 \mathrm{E}-01$ & $2.71 \mathrm{E}-03$ & $1.45 \mathrm{E}-03$ \\
\hline Cement A-2 & $5.56 \mathrm{E}-03$ & $1.14 \mathrm{E}-01$ & $1.38 \mathrm{E}-01$ & $4.10 \mathrm{E}-01$ & $2.74 \mathrm{E}-03$ & $1.69 \mathrm{E}-03$ \\
\hline Cement A-3 & $5.50 \mathrm{E}-03$ & $1.11 \mathrm{E}-01$ & $1.47 \mathrm{E}-01$ & $4.04 \mathrm{E}-01$ & $2.83 \mathrm{E}-03$ & $1.72 \mathrm{E}-03$ \\
\hline Cement B-2 & $5.84 \mathrm{E}-03$ & $1.37 \mathrm{E}-01$ & $1.60 \mathrm{E}-01$ & $3.66 \mathrm{E}-01$ & $4.20 \mathrm{E}-03$ & $1.05 \mathrm{E}-03$ \\
\hline Cement B-2 & $5.82 \mathrm{E}-03$ & $1.50 \mathrm{E}-01$ & $1.65 \mathrm{E}-01$ & $4.02 \mathrm{E}-01$ & $4.26 \mathrm{E}-03$ & $9.79 \mathrm{E}-04$ \\
\hline Cement B-3 & $5.38 \mathrm{E}-03$ & $1.21 \mathrm{E}-01$ & $1.64 \mathrm{E}-01$ & $3.80 \mathrm{E}-01$ & $4.98 \mathrm{E}-03$ & $1.07 \mathrm{E}-03$ \\
\hline Cement C-1 & $3.90 \mathrm{E}-03$ & $9.52 \mathrm{E}-02$ & $9.74 \mathrm{E}-02$ & $2.37 \mathrm{E}-01$ & $2.09 \mathrm{E}-03$ & $8.71 \mathrm{E}-04$ \\
\hline Cement C-2 & $3.60 \mathrm{E}-03$ & $9.20 \mathrm{E}-02$ & $9.02 \mathrm{E}-02$ & $1.97 \mathrm{E}-01$ & $2.07 \mathrm{E}-03$ & $1.00 \mathrm{E}-03$ \\
\hline Cement C-3 & $3.61 \mathrm{E}-03$ & $9.31 \mathrm{E}-02$ & $1.05 \mathrm{E}-01$ & $2.02 \mathrm{E}-01$ & $2.10 \mathrm{E}-03$ & $9.87 \mathrm{E}-04$ \\
\hline Cement D-1 & $3.27 \mathrm{E}-01$ & $8.01 \mathrm{E}+00$ & $7.44 \mathrm{E}+00$ & $2.04 \mathrm{E}+01$ & $1.23 \mathrm{E}-01$ & $4.38 \mathrm{E}-02$ \\
\hline Cement D-2 & $3.02 \mathrm{E}-01$ & $7.27 \mathrm{E}+00$ & $7.68 \mathrm{E}+00$ & $2.04 \mathrm{E}+01$ & $1.23 \mathrm{E}-01$ & $4.76 \mathrm{E}-02$ \\
\hline Cement D-3 & $2.59 \mathrm{E}-01$ & $5.82 \mathrm{E}+00$ & $6.63 \mathrm{E}+00$ & $1.90 \mathrm{E}+01$ & $1.23 \mathrm{E}-01$ & $5.82 \mathrm{E}-02$ \\
\hline Cement E-1 & $1.77 \mathrm{E}-03$ & $3.14 \mathrm{E}-02$ & $7.22 \mathrm{E}-02$ & $1.68 \mathrm{E}-01$ & $3.11 \mathrm{E}-03$ & $9.77 \mathrm{E}-04$ \\
\hline Cement E-2 & $1.77 \mathrm{E}-03$ & $3.20 \mathrm{E}-02$ & $7.51 \mathrm{E}-02$ & $2.19 \mathrm{E}-01$ & $3.11 \mathrm{E}-03$ & $9.71 \mathrm{E}-04$ \\
\hline Cement E-3 & $1.79 \mathrm{E}-03$ & $2.80 \mathrm{E}-02$ & $6.42 \mathrm{E}-02$ & $2.33 \mathrm{E}-01$ & $3.11 \mathrm{E}-03$ & $9.73 \mathrm{E}-04$ \\
\hline Ceramicrete-1 & $2.54 \mathrm{E}-04$ & $7.71 \mathrm{E}-02$ & $8.58 \mathrm{E}-02$ & $2.03 \mathrm{E}-01$ & $6.55 \mathrm{E}-03$ & $7.85 \mathrm{E}-04$ \\
\hline Ceramicrete-2 & $2.47 \mathrm{E}-04$ & $7.71 \mathrm{E}-02$ & $8.55 \mathrm{E}-02$ & $1.68 \mathrm{E}-01$ & $6.55 \mathrm{E}-03$ & $7.67 \mathrm{E}-04$ \\
\hline Ceramicrete-3 & $2.40 \mathrm{E}-04$ & $7.56 \mathrm{E}-02$ & $8.58 \mathrm{E}-02$ & $1.82 \mathrm{E}-01$ & $6.55 \mathrm{E}-03$ & $7.65 \mathrm{E}-04$ \\
\hline Hydroceramic A-1 & $1.38 \mathrm{E}-02$ & $8.37 \mathrm{E}-03$ & $1.95 \mathrm{E}-01$ & $2.80 \mathrm{E}-01$ & $3.42 \mathrm{E}-02$ & $2.28 \mathrm{E}-03$ \\
\hline Hydroceramic A-2 & $1.38 \mathrm{E}-02$ & $8.01 \mathrm{E}-03$ & $2.06 \mathrm{E}-01$ & $3.12 \mathrm{E}-01$ & $3.42 \mathrm{E}-02$ & $2.21 \mathrm{E}-03$ \\
\hline Hydroceramic A-3 & $1.36 \mathrm{E}-02$ & $1.00 \mathrm{E}-02$ & $1.94 \mathrm{E}-01$ & $2.99 \mathrm{E}-01$ & $3.42 \mathrm{E}-02$ & $2.38 \mathrm{E}-03$ \\
\hline Hydroceramic B-1 & $1.02 \mathrm{E}-02$ & $1.10 \mathrm{E}-02$ & $1.66 \mathrm{E}-01$ & $1.42 \mathrm{E}-01$ & $2.96 \mathrm{E}-02$ & $3.68 \mathrm{E}-03$ \\
\hline Hydroceramic B-2 & $9.93 \mathrm{E}-03$ & $8.50 \mathrm{E}-03$ & $1.54 \mathrm{E}-01$ & $1.13 \mathrm{E}-01$ & $2.96 \mathrm{E}-02$ & $3.75 \mathrm{E}-03$ \\
\hline Hydroceramic B-3 & $1.02 \mathrm{E}-02$ & $8.78 \mathrm{E}-03$ & $1.65 \mathrm{E}-01$ & $1.43 \mathrm{E}-01$ & $2.96 \mathrm{E}-02$ & $3.78 \mathrm{E}-03$ \\
\hline Hydroceramic C-1 & $6.81 \mathrm{E}-03$ & $5.33 \mathrm{E}-02$ & $2.58 \mathrm{E}-01$ & $3.85 \mathrm{E}-01$ & $4.61 \mathrm{E}-02$ & $1.37 \mathrm{E}-02$ \\
\hline Hydroceramic C-2 & $6.47 \mathrm{E}-03$ & $4.48 \mathrm{E}-02$ & $2.23 \mathrm{E}-01$ & $3.24 \mathrm{E}-01$ & $4.61 \mathrm{E}-02$ & $1.37 \mathrm{E}-02$ \\
\hline Hydroceramic C-3 & $6.19 \mathrm{E}-03$ & $3.66 \mathrm{E}-02$ & $1.91 \mathrm{E}-01$ & $2.77 \mathrm{E}-01$ & $4.61 \mathrm{E}-02$ & $1.33 \mathrm{E}-02$ \\
\hline
\end{tabular}


Table 15. Average of Triplicate PCT Results Expressed $10^{-3} \mathrm{~g} / \mathrm{m}^{2}$

\begin{tabular}{|c|c|c|c|c|c|c|c|}
\hline Monolith Tested & pH & $\begin{array}{c}\text { Al } \\
\left(\mathrm{g} / \mathrm{m}^{2} \times 10^{-3}\right)\end{array}$ & $\begin{array}{c}\text { Cs } \\
\left(\mathrm{g} / \mathrm{m}^{2} \times 10^{-3}\right)\end{array}$ & $\begin{array}{c}\mathrm{Na} \\
\left(\mathrm{g} / \mathrm{m}^{2} \times 10^{-3}\right)\end{array}$ & $\begin{array}{c}\operatorname{Re} \\
\left(\mathrm{g} / \mathrm{m}^{2} \times 10^{-3}\right)\end{array}$ & $\begin{array}{c}\mathrm{S} \\
\left(\mathrm{g} / \mathrm{m}^{2} \times 10^{-3}\right)\end{array}$ & $\begin{array}{c}\mathrm{Si} \\
\left(\mathrm{g} / \mathrm{m}^{2} \times 10^{-3}\right)\end{array}$ \\
\hline Cement A-Avg & 12.1 & 5.82 & 119 & 146 & 420 & 2.76 & 1.62 \\
\hline Cement B-Avg & 12.2 & 5.68 & 136 & 163 & 382 & 4.48 & 1.03 \\
\hline Cement C-Avg & 12.23 & 3.71 & 93.4 & 97.6 & 212 & 2.09 & 0.953 \\
\hline Cement D-Avg & 12.21 & 296 & 7040 & 7250 & 19,900 & 123 & 49.8 \\
\hline Cement E-Avg & 12.29 & 1.78 & 30.5 & 70.5 & 206 & 3.11 & 0.974 \\
\hline Ceramicrete-Avg & 11.61 & 0.247 & 76.6 & 85.7 & 185 & 6.55 & 0.772 \\
\hline Hydroceramic A-Avg & 10.11 & 13.7 & 8.80 & 198 & 297 & 34.2 & 2.29 \\
\hline Hydroceramic B-Avg & 11.04 & 10.1 & 9.41 & 161 & 132 & 29.6 & 3.74 \\
\hline Hydroceramic C-Avg & 11.19 & 6.49 & 44.9 & 224 & 329 & 46.1 & 13.6 \\
\hline Hanford Specification & $\mathrm{N} / \mathrm{A}$ & 2000 & 2000 & 2000 & 2000 & 2000 & 2000 \\
\hline
\end{tabular}


The average $\mathrm{pH}$ values from Table 15 are plotted in Figure 10. The $\mathrm{pH}$ values of the leachates after 7 day PCT testing for the cement monoliths and the hydroceramic monoliths are higher than those of the Ceramicrete monolith. This is likely due to the fact that phosphate ions are known to buffer leachate $\mathrm{pH}$ values during dissolution. Moreover, the $\mathrm{pH}$ values of the cements and the hydroceramics are greater than the $\mathrm{pH}$ values exhibited by some of the bed products tested in 2003-2004 indicating that the aluminate buffer capacity of the FBSR product is probably being exceeded by the cement and hydroceramic binders.

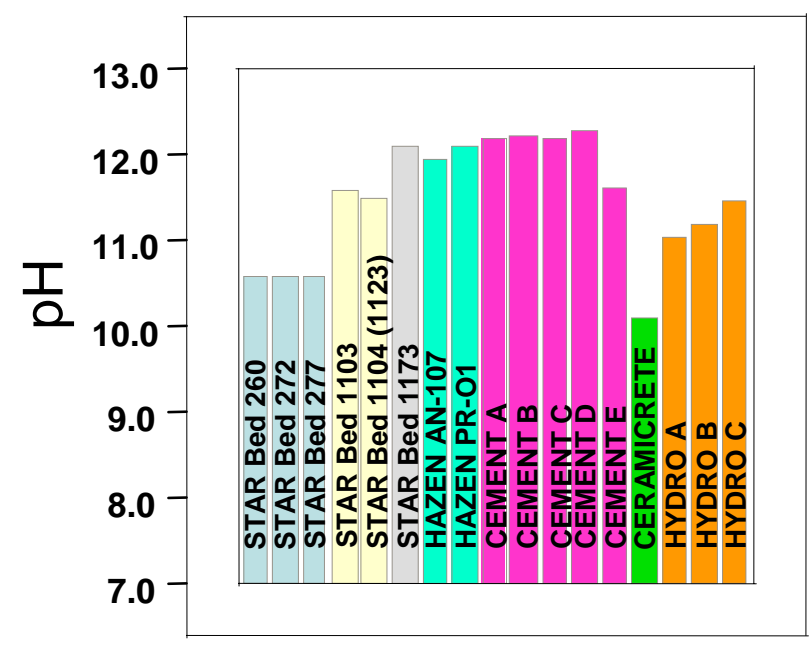

Figure 10. Monolith $\mathrm{pH}$ values from PCT testing compared to $\mathrm{pH}$ values of initial FBSR bed products.

The PCT leachate analyses for elements Al, Si, S, Cs, Na and Re from Table 15 are shown graphically in Figure 11 and Figure 12 . This figure indicates that all of the elements leach at $<2$ $\mathrm{g} / \mathrm{m}^{2}\left(2000 \times 10^{-3}\right.$ in the units shown on the figure) except for those of Cement formulation D. Whereas the leaching trends of the alkali ( $\mathrm{Na}$ and $\mathrm{Cs}$ ) in the bed products was highly correlated with the Al release suggesting an aluminosilicate buffering mechanism was occurring, these trends were not observed when the same bed products were embedded in the monolithing binders tested in this study. In addition, before being monolithed the Re, S, and $\mathrm{Si}$ in the bed products were a strong function of solution $\mathrm{pH}$ and the leaching trends of $\mathrm{Re}$ with $\mathrm{S}$ appeared to track each other. These trends are not observed in the monolith leach results. This is likely due to interactions of the binder phases (calcium silicates in cement, magnesium phosphates in Ceramicrete, and zeolites in hydroceramics) with the leachate which complicates the interpretation of the leachate analyses.

Of great importance is the durability of the monolithed FBSR in terms of the Hanford specification for $\mathrm{Na}$ release $\left(<2 \mathrm{~g} / \mathrm{m}^{2}\right)$ which ensures that the $\mathrm{Tc}^{99}$ release is $<2 \mathrm{~g} / \mathrm{m}^{2}$ in a congruently dissolving glass. In the FBSR product Re was used as a simulant for $\mathrm{Tc}^{99}$ and Figure 12 and Table 15 indicates that the $\mathrm{Na}$ and $\mathrm{Re}$ are not released congruently, e.g. $\mathrm{Re}$ is released at lower rates than $\mathrm{Na}$ except for Cement $\mathrm{D}$. This type of incongruent leaching behavior has been widely observed for multiphase ceramic and mineral waste forms. ${ }^{40}$ 

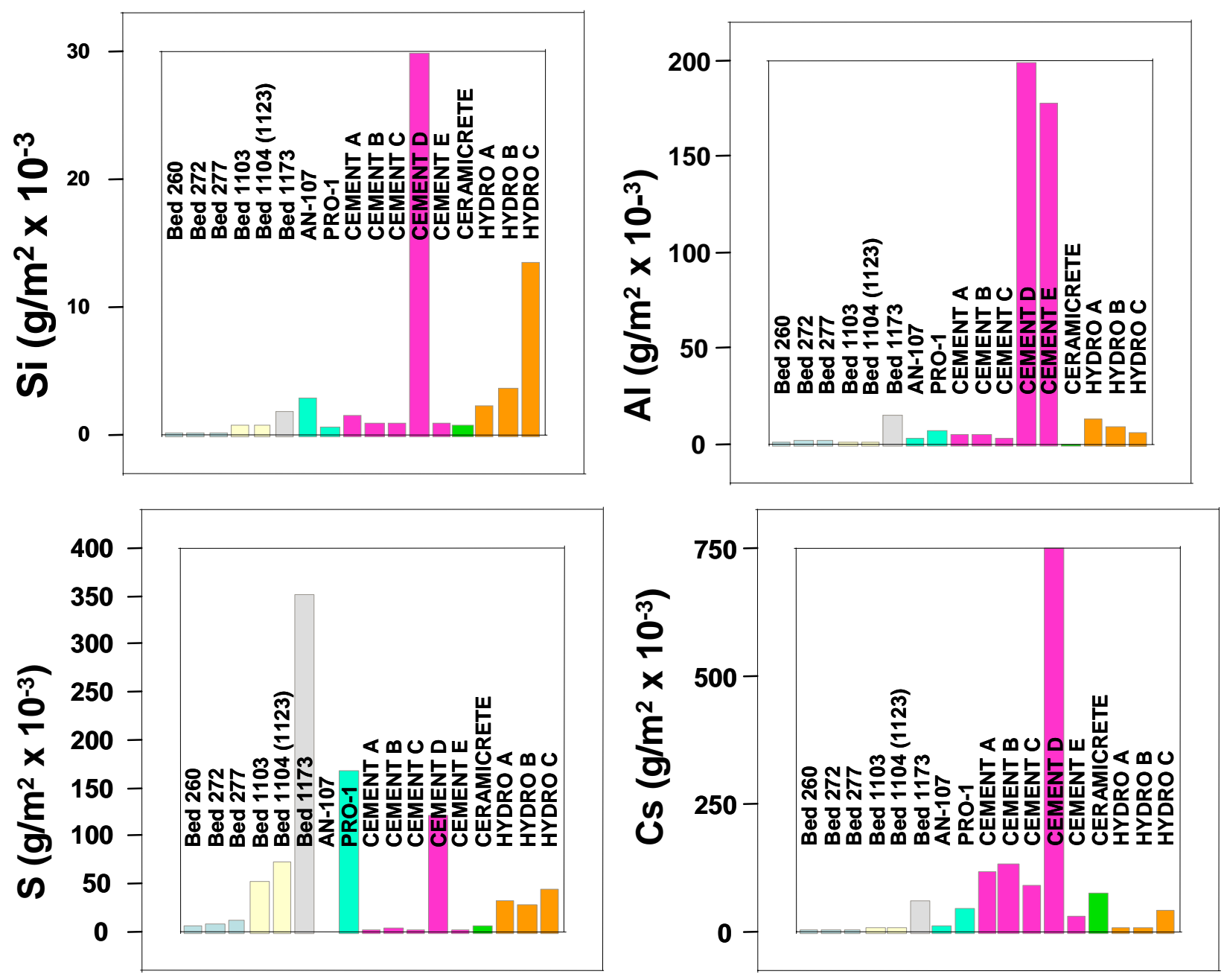

Figure 11. PCT triplicate leachate analyses for $\mathrm{Al}, \mathrm{Si}, \mathrm{S}$, and $\mathrm{Cs}$ in $\mathrm{g} / \mathrm{m}^{2}$. 
WSRC-STI-2006-00033

Revision 1
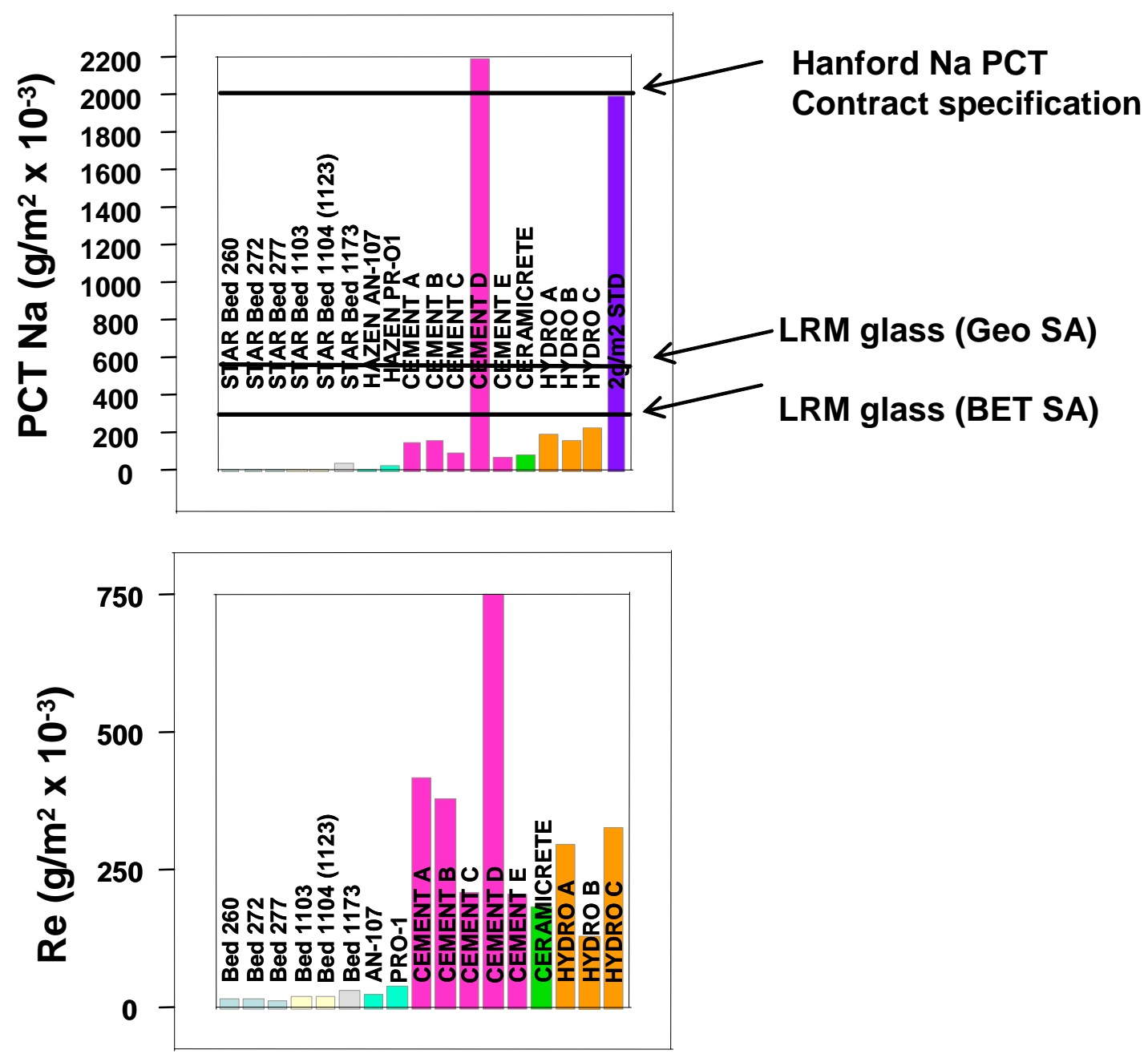

Figure 12. PCT triplicate leachate analyses for $\mathrm{Na}$ and $\mathrm{Re}$ in $\mathrm{g} / \mathrm{m}^{2}$. 


\subsection{CONCLUSIONS}

Table 16 indicates that three cement formulations and one hydroceramic formulation met all of the monolith development criteria including waste loading for Hanford LAW Envelope A, compressive strength, and durability based on $\mathrm{Na}$ and Re via the PCT.

Table 16. Summary of Monolith Performance Vs. Development Criteria

\begin{tabular}{|l|c|c|c|}
\hline Monolith & $\begin{array}{c}\text { Waste Loading } \\
\text { Criteria for } \\
\text { Hanford LAW } \\
\text { Envelope A }\end{array}$ & $\begin{array}{c}\mathbf{2 5 0 0} \text { psi } \\
\text { Compressive } \\
\text { Strength }\end{array}$ & $\begin{array}{c}\text { PCT Durability } \\
<\mathbf{2 g} / \mathbf{m}^{\mathbf{2}}\end{array}$ \\
\hline Cement A & YES & YES & YES \\
\hline Cement B & YES & YES & YES \\
\hline Cement C & YES & YES & YES \\
\hline Cement D & YES & YES & NO \\
\hline Cement E & YES & NO & YES \\
\hline Ceramicrete & NO** & YES & YES \\
\hline Hydroceramic-A & NO & NO & YES \\
\hline Hydroceramic-B & NO & YES & YES \\
\hline Hydroceramic-C & YES & YES & YES \\
\hline
\end{tabular}

** Not an optimized waste loading, additional testing is required to demonstrate acceptable performance with higher waste loadings.

\subsection{RECOMMENDATIONS/PATH FORWARD}

The following are recommended for further study:

- Perform multiple BET analyses on mixture that are subsequently formed into monoliths. Mixtures may contain more fines than shown in current analyses

- Perform PCT on Set \#3 hydroceramics cured at $90^{\circ} \mathrm{C}$

- Perform MCC-1 monolith tests for comparison to PCT results

- Evaluate additional binders that may be more compatible with the FBSR products including high $\mathrm{Al}_{2} \mathrm{O}_{3}$ containing cements and geopolymers which are made with kaolin clay and water glass and have been demonstrated at the pilot scale for mining wastes. 
- Test limits of Ceramicrete to maximize waste loading within limits of compressive strength. Goal for additional testing is to achieve a minimum of $75 \%$ FBSR product loading in monolith on a dry basis.

- Make larger monoliths to identify scale up issues.

- Perform economic analyses related to monolith scale up and production costs for each of the various acceptable binder matrices.

- Examine monolith matrix by Scanning Electron Microscopy (SEM) to see if the FBSR product is encapsulated or if there is reaction with the binder.

- Design experiments to determine if there is a component of the leach rate that is dependent on macro encapsulate by the binder.

\subsection{ACKNOWLEDGEMENTS}

The authors would like to gratefully acknowledge the assistance of Sherry Vissage and Phyllis Workman of Savannah River National Laboratory in helping complete the experiments. This paper was prepared in connection with work done under Contract No. DE-AC09-96SR18500 with the U.S. Department of Energy (DOE). Specifically, the research was supported in part by a Work for Others (WFO-06-01) with THOR Treatment Technologies. 
WSRC-STI-2006-00033

Revision 1

\subsection{REFERENCES}

1 Jantzen, C.M., "Characterization and Performance of Fluidized Bed Steam Reforming (FBSR) Product as a Final Waste Form," Ceramic Transactions 155, 319-329 (2004).

2 Pareizs, J.M., Jantzen, C.M., Lorier, T.H. "Durability Testing of Fluidized Bed Steam Reformer (FBSR) Waste Forms for High Sodium Wastes at Hanford and Idaho," U.S. DOE Report WSRC-TR-2005-00102 (2005).

3 Jantzen, C.M., Pareizs, J.M., Lorier, T.H. and Marra, J.C. (2005). "Durability Testing of Fluidized Bed Steam Reforming (FBSR) Products," Ceramic Transactions, 176, 121-137 (2005).

4 Jantzen, C.M. Lorier, T.H., Marra, J.C., and Pareizs, J.P., “Durability Testing of Fluidized Bed Steam Reforming (FBSR) Waste Forms," Waste Management '06, Paper \#6373 (2006).

5 McGrail, B.P.; Schaef, H.T.; Martin, P.F.; Bacon, D.H.; Rodriguez, E.A.; McCready, D.E.; Primak, A.N.; Orr, R.D., "Initial Evaluation of Steam-Reformed Low Activity Waste for Direct Land Disposal," U.S. DOE Report PNWD-3288 (2003).

6 Lorier, T.H., Pareizs, J.M. and Jantzen, C.M., "Single Pass Flow Through (SPFT) Testing of Fluidized Bed Steam Reforming (FBSR) Waste Forms," U.S. DOE Report, WSRCTR-2005-00124 (2005).

7 McGrail, B.P., "Laboratory Testing of Bulk Vitrified and Steam-Reformed LowActivity Forms to Support a Preliminary Assessment for an Integrated Disposal Facility," U.S. DOE Report PNNL-14414 (2003).

8 Puura, E. and Neretnieks, I., "Atmospheric Oxidation of the Pyritic Waste Rock in Maardu, Estonia, 2: An Assessment of Aluminosilicate Buffering Potential," Environ Geol. 39 [6], 560-566 (2000)

9 Waste Acceptance Product Specifications for Vitrified High-Level Waste Forms, U.S. DOE, Office of Environmental Restoration and Waste Management, U.S. DOE Document EMWAPS, Rev.0, Washington, DC (February 2003).

10 Jantzen,C.M., Bibler, N.E., Beam, D.C. and Pickett, M.A., "Characterization of the Defense Waste Processing Facility (DWPF) Environmental Assessment (EA) Glass Standard Reference Material," U.S. DOE Report WSRC-TR-92-346, Rev. 1, Westinghouse Savannah River Company, Aiken, SC (February 1993). 
WSRC-STI-2006-00033

Revision 1

11 U.S. Department of Energy, "Environmental Assessment-Waste Form Selection for SRP High-Level Waste,” U.S. DOE Report DOE/EA-0179, Washington, DC (1982).

12 Bibler, N. E., and Bates, J. K., "Product Consistency Leach Tests of Savannah River Site Radioactive Waste Glasses," Scientific Basis for Nuclear Waste Management, XIII, Oversby, V. M. and Brown, P. W., eds., Materials Research Society, Pittsburgh, PA, 1990, pp. 327-338.

13 Bates, J. K., Lam, D. J., and Steindler, M. J., "Extended Leach Studies of Actinide-Doped SRL 131 Glass," Sci. Basis for Nucl. Waste Mgt., VI, D. G. Brookins (Ed.), North-Holland, NY, 183-190 (1983).

14 Bibler, N. E. and Jurgensen, A. R., "Leaching Tc-99 from SRP Glass in Simulated Tuff and Salt Groundwaters," Sci. Basis for Nucl. Waste Mgt., XI, M.J. Apted and R.E. Westerman (eds.), Mat. Res. Soc., Pittsburgh, PA, 585-593 (1988).

15 Bradley, D. J., Harvey, C. O., and Turcotte, R. P., "Leaching of Actinides and Technetium from Simulated High-Level Waste Glass," U.S. DOE Report PNL-3152, Pacific Northwest Laboratory, Richland, WA (1979).

16 Fillet, S., Nogues, J., Vernaz, E., and Jacquet-Francillon, N., "Leaching of Actinides from the French LWR Reference Glass," Sci. Basis for Nucl. Waste Mgt., IX, L. O. Werme, Mat. Res. Soc., Pittsburgh, PA, 211-218 (1985).

17 Bazan, F., Rego, J., and Aines, R. D., "Leaching of Actinide-doped Nuclear Waste Glass in a Tuff-Dominated System," Sci. Basis for Nucl. Waste Mgt., X, J. K. Bates and W. B. Seefeldt (eds.), Mat. Res. Soc., Pittsburgh, PA, 447-458 (1987).

18 Vernaz E. Y. and Godon, N., "Leaching of Actinides from Nuclear Waste Glass: French Experience," Sci. Basis for Nucl. Waste Mgt., XV, C. G. Sombret (ed.), Mat. Res. Soc., Pittsburgh, PA, 37-48 (1992).

19 Ebert, W. L., Wolf, S. F., and Bates, J. K., "The Release of Technetium from Defense Waste Processing Facility Glasses," Sci. Basis for Nucl. Waste Mgt., XIX, W. M. Murphy and D. A. Knecht (eds.), Mat. Res. Soc., Pittsburgh, PA, 221-227 (1996).

20 McGrail, B. P., "Waste Package Component Interactions with Savannah River Defense Waste Glass in a Low-Magnesium Salt Brine," Nuclear Technology, 168-186 (1986).

21 D.A. Burbank, "Waste Acceptance Criteria for the Immobilized Low-Activity Waste Disposal Facility," US DOE Report RPP-8401, Rev. 0, CH2M HILL Hanford Group, Richland, WA (May 2002). 
WSRC-STI-2006-00033

Revision 1

22 ANSI/ANS-16.1, "Measurement of the Leachability of Solidified Low-Level Radioactive Wastes by a Short Term Test Procedure," American National Standards

Institute/American Nuclear Society, La Grange Park, IL

23 DOE/ORP Contract with Bechtel, National, Inc., "Design, Construction, and Commissioning of the Hanford Tank Waste Treatment and Immobilization Plant," Contract Number DE-AC27-01RV14136, U.S. Department of Energy, Office of River Protection, Richland, WA (December 2000).

24 U.S. Nuclear Regulatory Commission, "Technical Position on Waste Form (Revision 1)," US NRC Low-Level Waste Management Branch Division of Low-Level Waste management and Decommissioning (January 1991).

25 Lea, F.M., The Chemistry of Cement and Concrete, Edward Arnold Publishers, Ltd., 727 pp (1970).

26 Soleberg, N.R., Marshall, D.W., Bates, S.O., Taylor, D.D., "Phase 2 THOR Steam Reforming Tests for Sodium Bearing Waste Treatment;" INEEL/EXT-04-01493; Idaho National Engineering \& Environmental Laboratory: Idaho Falls, ID (2004).

27 Olson, A.L., Soelberg, N.R., Marshall, D.W., Anderson, G.L. "Fluidized Bed Steam Reforming of INEEL SBW Using THOR ${ }^{\text {sm }}$ Mineralizing Technology," U.S. DOE Report INEEL/EXT-04-02564 (2004).

28 Olson, A.L., Soelberg, N.R., Marshall, D.W.,Anderson, G.L., "Fluidized Bed Steam Reforming of Hanford LAW Using THOR ${ }^{\text {sm }}$ Mineralizing Technology," U.S. DOE Report INEEL/EXT-04-02492; Idaho National Engineering \& Environmental Laboratory: Idaho Falls, ID (2004).

29 Bullock, Jr. J.H, Cathcart, J.D., Betterton, W.J., “Analytical Methods Utilized by the United States Geological Survey for the Analysis of Coal and Coal Combustion Byproducts," US Geological Survey: Denver, CO (2002).

30 Crow, R.F.; Connolly, J.D. "Atomic Absorption Analysis of Portland Cement and Raw Mix Using Lithium Metaborate Fusion,” Jour. Test. Evaluation, 1, 382 (1973).

31 ASTM C1463. Annual Book of ASTM Standards, Vol. 12.01, "Practice for Dissolving Glass Containing Radioactive and Mixed Waste for Chemical and Radiochemical Analysis"

32 ASTM C1317. Annual Book of ASTM Standards, Vol. 12.01, "Standard Practice for Dissolution of Silicate or Acid-Resistant Matrix Samples" 
WSRC-STI-2006-00033

Revision 1

33 Wagh, A.S., Maloney, M.D., Thomson, G.H., Antink, A., "Investigations in Ceramicrete Stabilization of Hanford Tank Wastes," WM'03 (2003).

34 Bao, Y., Grutzeck, M.W. and Jantzen C.M. "Preparation and Properties of Hydroceramic Waste Forms Made with Simulated Hanford Low Activity Waste (LAW)," J. Am. Ceramic Soc., 88 [12], 3287-3302 (2005).

35 ASTM D 1193. Annual Book of ASTM Standards, Vol. 11.01, "Specification for Reagent Water"

36 ASTM C1285. Annual Book of ASTM Standards, Vol. 12.01, "Standard Test Methods for Determining Chemical Durability of Nuclear, Hazardous, and Mixed Waste Glasses and Multiphase Glass Ceramics: The Product Consistency Test (PCT)"

37 Brunauer, S.; Emmett, P.H.; Teller, E., “Adsorption of Gases in Multimolecular Layers," Journal of Physical Chemistry 60:309-319 (1938).

38 Ebert, W. L. "The Effects of the Glass Surface Area/Solution Volume Ratio on Glass Corrosion: A Critical Review," U.S. DOE Report ANL-94/34, Argonne National Laboratory: Argonne, IL (1995).

39 Jantzen, C.M., Pickett, J.B., Brown, K.G., Edwards, T.B., and Beam, D.C., "Process/Product Models for the Defense Waste Processing Facility (DWPF): Part II. Appendix G, "Predicting Glass Durability from Composition Using a Thermodynamic Hydration Energy Reaction MOdel (THERMO)," US DOE Report WSRC-TR-93-0672, 464p. (1995).

40 Jantzen, C.M., Clarke, D.R., Morgan, P.E.D. and Harker, A.B., "Leaching of Polyphase Nuclear Waste Ceramics: Microstructural and Phase Characterization," J. Am. Ceram. Soc., 65[6], 292-300 (1982). 


\section{Distribution:}

Savannah River National Laboratory

G.T. Wright, todd.wright@srnl.doe.gov

R.E. Edwards, richard.edwards@srnl.doe.gov

D. A. Crowley, david.crowley@srnl.doe.gov

J.C. Marra, james.marra@srnl.doe.gov

THOR Treatment Technologies

M. P. McNamara, mike.mcnamara@wsms.com

D. Schmoker, duane.schmoker@wgint.com

B. Mason,bmason@studsvik-inc.com

K.Ryan, kevin.ryan@wgint.com

P.W. Gibbons, pwgibbons@cbcgllc.com

File - 5 